Article

\title{
Acid and Thermal Treatment of Alkali-Activated Zeolite Foams
}

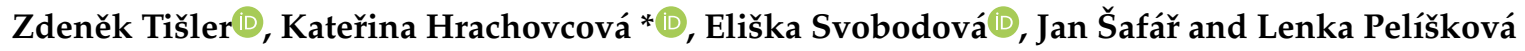 \\ Unipetrol Centre for Research and Education, a.s, Areál Chempark 2838, Záluží 1, 43670 Litvinov, \\ Czech Republic; zdenek.tisler@unicre.cz (Z.T.); Eliska.Svobodova@unicre.cz (E.S.); Jan.Safar@unicre.cz (J.Š.); \\ Lenka.Peliskova@unicre.cz (L.P.) \\ * Correspondence: katerina.hrachovcova@unicre.cz
}

Received: 17 October 2019; Accepted: 18 November 2019; Published: 20 November 2019

\begin{abstract}
The foamed alkali-activated zeolite materials have been studied primarily in terms of mechanical and structural properties as potential substitutes for concrete and other building materials. However, they also have interesting textural and acid properties that make them much more useful, especially in the chemical industry. The aim of the study is to map in detail the influence of post-synthesis modifications of alkali-activated natural zeolite foams on their chemical, mechanical, and textural properties for possible use in catalytic and adsorption applications. Alkali-activated natural zeolite foam pellets were prepared by activation with mixed potassium hydroxide and sodium silicate activator and foamed using $\mathrm{H}_{2} \mathrm{O}_{2}$ solution. The foam pellets were post-synthetic modified by leaching with mineral and organic acids and calcination. The properties of the modified materials were characterised on the basis of XRF, XRD, $\mathrm{N}_{2}$ physisorption, DRIFT, SEM, $\mathrm{NH}_{3}$-TPD analyses, and the strength measurements. Our data showed that the basic clinoptilolite structure remains unchanged in the material which is stable up to $600^{\circ} \mathrm{C}$ after acid leaching. In two-step leaching, the specific surface area increases to $350 \mathrm{~m}^{2} / \mathrm{g}$ and the leaching process allows the acid properties of the materials to be varied.
\end{abstract}

Keywords: natural zeolite; clinoptilolite; alkali activation; inorganic foam; acid leaching

\section{Introduction}

Alkali-activated foamed zeolites represent a new group of materials potentially useful in the chemical industry, especially in the field of catalysis and sorption. The use of the zeolite materials is limited primarily to building applications, especially as a substitute for concrete, ceramic materials, and thermal insulation. Natural zeolites are mainly used as sorbents for the purification of water $\left(\mathrm{Cs}^{+}\right.$, $\mathrm{Rb}^{+}$, and $\mathrm{NH}_{4}{ }^{+}$) and gases $\left(\mathrm{NH}_{3}\right)$ [1,2]. Alkali-activated materials are similar to zeolites but have an amorphous structure and do not form crystalline structures as do zeolites. In the case of alkaline activation of metakaolin (geopolymerization), the original layered structure is completely dissolved, and a new amorphous network is formed. The amorphous network is formed by an N(K)-A-S-H matrix exhibiting zeolite-like properties. In contrast, alkaline activation of natural zeolites containing predominantly clinoptilolite produces a composite material composed of the original structure and the binder $\mathrm{N}(\mathrm{K})-\mathrm{A}-\mathrm{S}-\mathrm{H}$ matrix from the original zeolite (clinoptilolite). The $\mathrm{N}(\mathrm{K})-\mathrm{A}-\mathrm{S}-\mathrm{H}$ matrix is formed by dissolving the surface of the individual grains and the accompanying minerals which in the case of natural zeolites are other aluminosilicate minerals such as feldspars, mica, and clays [3].

Clinoptilolite is a zeolite from the heulandite group. Both zeolites (clinoptilolite and heulandite) are isostructural and are distinguished by the $\mathrm{Si} / \mathrm{Al}$ ratio, where a mineral with a $\mathrm{Si} / \mathrm{Al}$ ratio greater than 4 is called clinoptilolite. The zeolite grid consists of tetrahedrons $\left[\mathrm{SiO}_{4}\right]$ and $\left[\mathrm{AlO}_{4}\right]^{-}$.Tetrahedrons are organized into porous structures formed by a system of interconnected channels. The clinoptilolite 
contains three types of these channels. Two types of the channels are a parallel eight-member ring and 10-member ring, and the third type eight-member ring intersects them [4]. The pore structure of natural zeolites is not perfect, pores are not perfectly developed or are blocked by accompanying minerals (spar, mica, clays, etc.) or amorphous $\mathrm{SiO}_{2}$ structures that have formed during hydrothermal synthesis of the zeolitic rock [5]. Pore blocking is particularly evident on the low specific surface area of natural zeolites, which is usually in the range of units up to several tens of $\mathrm{m}^{2} / \mathrm{g}$ [6]. However, these pores can be purified and made available by methods such as acid leaching [7-9]. Purified and available pores make the material usable in other applications. Acid leaching can also be used to prepare materials obtained by alkaline activation of metakaolin [10-12] or natural zeolites [3].

Acid leaching (dealumination) is often used for post-synthesis modification of synthetic zeolites to remove framework aluminium (FAL) and thereby increase the $\mathrm{Si} / \mathrm{Al}$ molar ratio. Most commonly, strong mineral acids $\left(\mathrm{HCl}, \mathrm{HNO}_{3}, \mathrm{H}_{2} \mathrm{SO}_{4}\right)$ or organic acids (oxalic, citric) [13] are used. Organic acids simultaneously act as chelating agents and are usually more effective to remove $\mathrm{Al}$ from the structure. The removal of $\mathrm{Al}$ often leads to a disruption of the zeolite structure and the formation of octahedral coordinated extra framework aluminium (EFAL) inside the pores [14]. EFAL creates strong acid Lewis centres formed by $\mathrm{AlO}^{+}, \mathrm{Al}(\mathrm{OH})^{2+}$, and $\mathrm{Al}(\mathrm{OH})_{2}{ }^{+}$groups [15]. Brønsted acidity of zeolites is generally attributed to bridging hydroxyl groups $(\mathrm{Si}-(\mathrm{OH})-\mathrm{Al})$. Therefore, the concentration of the Brønsted sites is directly related to the number of FAL atoms $[16,17]$. Acid leaching in the material creates another additional mesoporosity which is important for the transport of larger molecules. Easier permeability is supported by the presence of macropores formed in the preparation of zeolite foam by foaming of the alkali-activated mixture with powder metals or hydrogen peroxide solution. In the reaction of powder metals or hydrogen peroxide solution (strong alkaline medium), gases are evolved and thus the mixture is foamed $[3,18]$.

The aim of the work was to find out the influence of acid leaching, especially the influence of time, temperature, leaching method and the concentration of hydrochloric acid, including leaching with other organic and mineral acids, on chemical, mechanical, and textural properties of foamed zeolites. An equally important parameter in the field of catalysis is the thermal resistance of the catalyst support and therefore the influence of the calcination temperature of the zeolite foam on the mentioned properties was studied. The post-synthetic modification will make it possible to increase the potential of these materials for further, not only constructional use, namely in catalytic and sorption applications.

\section{Materials and Method}

\subsection{Materials}

Analytical grade potassium hydroxide, hydrogen peroxide (30 wt \%), hydrochloric acid (35 wt \%), phosphoric acid (85 wt \%), sulphuric acid (98 wt \%), nitric acid (65 wt \%), oxalic acid (OXAL), tartaric acid (TART), and citric acid (CITR) were supplied by Lach-Ner s.r.o. Sodium silicate (Na—water glass) with silicate modulus 3.22 was purchased from Labar s.r.o. in a technical grade purity. The powdered natural zeolite from the Swiss company Unipoint AG (Ossingen, Switzerland) with the trade name Klinofeed ${ }^{\circledR}(\mathrm{KLI})$ and with the particle size distribution $d_{50}=28.9$ and $d_{90}=73.8 \mu \mathrm{m}$ was used for the preparation of the samples. The particle size distribution was determined by MASTERSIZER 2000 with HYDRO 2000 MU (Malvern Panalytical, Malvern, UK).

Klinofeed ${ }^{\circledR}$ contains at least $85 \mathrm{wt} \%$ of clinoptilolite, other minor mineral components present in Klinofeed ${ }^{\circledR}$ are clays $(9 \mathrm{wt} \%)$, feldspar $(4 \mathrm{wt} \%)$, mica $(2 \mathrm{wt} \%)$. The specific surface area of this natural zeolite is $24.6 \mathrm{~m}^{2} / \mathrm{g}$. The chemical composition was obtained by the XRF method and is shown in Table 1. 
Table 1. Chemical composition of natural zeolite Klinofeed ${ }^{\circledR}$.

\begin{tabular}{|c|c|c|c|c|c|c|c|c|c|c|c|}
\hline \multirow{2}{*}{ Sample } & \multicolumn{8}{|c|}{ Chemical Composition (wt \%) } & \multirow{2}{*}{ LOI * } & \multirow{2}{*}{ SUM } & \multirow{2}{*}{ Si/Al Ratio ** } \\
\hline & $\mathrm{SiO}_{2}$ & $\mathrm{Al}_{2} \mathrm{O}_{3}$ & $\mathrm{~K}_{2} \mathrm{O}$ & $\mathrm{Fe}_{2} \mathrm{O}_{3}$ & $\mathrm{CaO}$ & $\mathrm{Na}_{2} \mathrm{O}$ & $\mathrm{MgO}$ & $\mathrm{TiO}_{2}$ & & & \\
\hline KLI & 66.80 & 10.98 & 4.23 & 1.97 & 4.23 & 0.22 & 0.65 & 0.24 & 9.97 & 9.29 & 5.16 \\
\hline
\end{tabular}

\subsection{Synthesis of Zeolite Foams}

The pellets of the zeolite foam were obtained by the same procedure described in our previous publication [3] and the zeolite foam pellets were produced by the method described in the CZ 307364 patent. The natural zeolite (400 g) was activated using a mixed activator $(\mathrm{KOH}$ solution with a water glass) and foamed with a hydrogen peroxide solution. Parameters of the alkaline activator and the mixture:

- $\quad$ Silicate modulus (Ms):*

- Water coefficient $(\mathrm{w})$ :** $^{*}$

- Alkali content:

- Molar ratio:

- $\quad$ Foaming agent $\left(30 \mathrm{wt} \% \mathrm{H}_{2} \mathrm{O}_{2}\right)$ :

$$
\mathrm{Ms}=\left(\mathrm{SiO}_{2}\right) /\left(\mathrm{Me}_{2} \mathrm{O}\right)=1.51
$$

$\mathrm{w}=$ mwater $/$ mnatural zeolite $=0.7$

$\mathrm{Me}_{2} \mathrm{O}=8.2 \mathrm{wt} \%(\mathrm{Me}=\mathrm{K}+\mathrm{Na})$

$\mathrm{Na}_{2} \mathrm{O}: \mathrm{K}_{2} \mathrm{O}=0.56$

$0.125 \mathrm{wt} \%$

* Silicate modulus (Ms) is the molar ratio of $\mathrm{SiO}_{2}$ to $\mathrm{Me}_{2} \mathrm{O}(\mathrm{Me}=\mathrm{Na}, \mathrm{K})$.

${ }^{*}$ Water coefficient $(\mathrm{w})$ is the weight of the aluminosilicate compound (natural zeolite) to the weight of water in a mixture.

The foam was shaped into pellets of $5 \mathrm{~mm}$ in diameter, and the material was activated for $48 \mathrm{~h}$ at $50{ }^{\circ} \mathrm{C}$. Prepared pellets (Figure 1) were aged under laboratory conditions in a closed plastic bag for one month prior to further processing. A prepared sample is designated " $\mathrm{S}$ ".

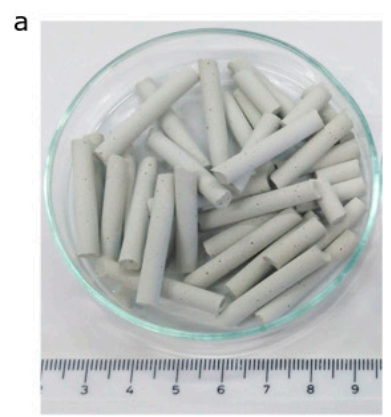

b

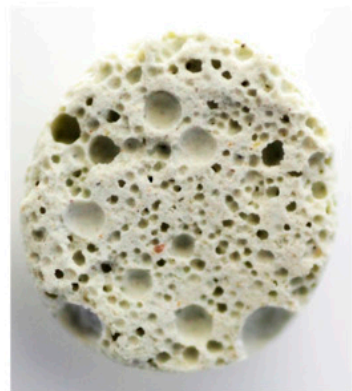

Figure 1. The prepared zeolite foam pellets (a) and cross-section of pellet $-5 \mathrm{~mm}$ diameter (b).

\subsection{Post-Synthesis Modifications of Zeolite Foams}

The sample of prepared foam pellets (S) was first dried overnight at $120^{\circ} \mathrm{C}$, then, part of them was leached in a beaker with a stirrer at $40{ }^{\circ} \mathrm{C}$ to $80^{\circ} \mathrm{C}$ using $0.1-6.0 \mathrm{M} \mathrm{HCl}$ for 1 to $6 \mathrm{~h}$. The solution ratio $(\mathrm{g} / \mathrm{mL})$ of the foam was 1:20 for all samples. The samples were after leaching washed under the flow of demineralized water until reaching neutral $\mathrm{pH}$ and then dried at $120^{\circ} \mathrm{C}$ overnight. The samples of this series were denoted as "temperature $\left(40-80^{\circ} \mathrm{C}\right) /$ time of leaching $(1-6 \mathrm{~h}) /$ concentration of $\mathrm{HCl}(0.1-6 \mathrm{M})$ ", e.g., $80 / 6 / 0.1$ was the sample leached at $80^{\circ} \mathrm{C}$ for $6 \mathrm{~h}$ by $0.1 \mathrm{M} \mathrm{HCl}$. The other part of 
pellets was leached by "two-step" acid leaching with a combination of 0.1 and $3 \mathrm{M} \mathrm{HCl}\left(80^{\circ} \mathrm{C} / 6 \mathrm{~h}\right)$. The sample was denoted as $0.1 \mathrm{M}+3 \mathrm{M}$. The second part of pellets was leached by different mineral and organic acids with $1 \mathrm{M}$ concentration at $80{ }^{\circ} \mathrm{C}$ for $6 \mathrm{~h}$. The samples were denoted as "acid $\left(\mathrm{H}_{3} \mathrm{PO}_{4}\right.$, $\left.\mathrm{H}_{2} \mathrm{SO}_{4}, \mathrm{HNO}_{3}, \mathrm{OXAL}, \mathrm{CITR}, \mathrm{TART}\right)^{\prime \prime}$. The two-step leached samples were subsequently calcined from 300 to $1000{ }^{\circ} \mathrm{C}$ for $6 \mathrm{~h}$ (heating rate $1^{\circ} \mathrm{C} / \mathrm{min}$ ). The samples were denoted as " $120^{\prime \prime}$ for dried $0.1 \mathrm{M}+3 \mathrm{M}$ or "calcination temperature $300-1000^{\circ} \mathrm{C}^{\prime \prime}$ for calcined samples.

\subsection{Characterisation}

The chemical composition of foams was determined by X-ray fluorescence analysis (XRF) using S8 Tiger (Bruker AXS GmbH, Karlsruhe, Germany) with Rh cathode. The results were processed by Spectra plus software (Version 3).

The crystal phase identification was performed by X-ray diffraction (XRD) analysis and the crystallinity at $2 \theta 9.9^{\circ}$ [020] was determined. The instrument D8 Advance ECO powder diffractometer (Bruker AXS GmbH, Karlsruhe, Germany) was used for XRD with CuK $\alpha$ radiation $(\lambda=1.5406 \AA)$. The resolution of $0.02^{\circ}$ and the period of 0.5 were used. The measurements were performed over a $2 \theta$ range of $5^{\circ}$ to $70^{\circ}$ and evaluated by the Diffrac.EVA software (Bruker AXS GmbH, Karlsruhe, Germany) using the Powder Diffraction File Database (PDF $4+2018$, International Centre for Diffraction Data, Newtown Square, PA, USA).)

The textural properties were determined by $\mathrm{N}_{2}$ physisorption at $-196{ }^{\circ} \mathrm{C}$ using an Autosorb iQ (Quantachrome Instruments, Boynton Beach, FL, USA) and by mercury porosimetry using an AutoPore IV 9510 (Micromeritics Instrument Corporation, Norcross, GA, USA). The specific surface area (BET) was determined by $\mathrm{N}_{2}$ adsorption/desorption. Samples for BET were dried under vacuum before the analysis. Drying was carried out in glass cells at $110^{\circ} \mathrm{C}$ and drying of the calcined samples at $200{ }^{\circ} \mathrm{C}$ for $16 \mathrm{~h}$. Macroporous properties were determined using mercury porosimetry. Samples for mercury porosimetry were dried under vacuum at $110{ }^{\circ} \mathrm{C}$ for $16 \mathrm{~h}$.

SEM images were obtained by scanning electron microscope (SEM) JSM-7500F (JEOL Ltd., Tokyo, Japan) with a cold cathode-field emission SEM with parameters of measurements $1 \mathrm{kV}$ and GB high mode.

Diffuse reflectance infrared Fourier transform spectroscopy (DRIFT) of dried and calcined samples was obtained using Nicolet iS 10 (Thermo Scientific, Waltham, MA, USA). The sample (15 mg) was mixed with $300 \mathrm{mg}$ of $\mathrm{KBr}$ and analysed. The parameters of the analysis were: Number of scans 128 and resolution $2 \mathrm{~cm}^{-1}$. Gaussian deconvolution of broadband at approximately $850-1350 \mathrm{~cm}^{-1} \mathrm{was}^{-}$ used for a detailed analysis of the measured data.

The strength in the cutting edge was measured on 10 samples using UMZ-3k (Micro-Epsilon, Bechyně, Czech Republic) with a corresponding trapezoidal flat blade attachment (area size $1 \mathrm{~mm}$ ). Maximum strength parameter $375 \mathrm{~N}$, load speed $10 \mathrm{~mm} / \mathrm{min}$. Results were obtained by statistical data processing.

The acid properties of the samples were determined by ammonia temperature-programmed desorption ( $\mathrm{NH}_{3}$-TPD) using Autochem $2950 \mathrm{HP}$ device (Micromeritics Instrument Corporation, Norcross, GA, USA). Powdered sample $(100 \mathrm{mg})$ was weighed into a quartz tubular reactor with a quartz wool plug. First, the sample was pre-treated by heating to $450{ }^{\circ} \mathrm{C}$ (heating rate $10{ }^{\circ} \mathrm{C} / \mathrm{min}$ ) in the flow of pure helium (flow rate $25 \mathrm{~mL} / \mathrm{min}$ ). After reaching $450{ }^{\circ} \mathrm{C}$, the sample was cooled down to $100{ }^{\circ} \mathrm{C}$. Then, the sample was saturated with ammonia by a flowing gas mixture containing $90 \mathrm{vol} \%$ of He and $10 \mathrm{vol} \%$ of ammonia (flow rate $25 \mathrm{~mL} / \mathrm{min}$ ) for $30 \mathrm{~min}$. Weakly bounded $\mathrm{NH}_{3} \mathrm{molecules}$ were removed by flushing the sample out in the flow of helium ( $25 \mathrm{~mL} / \mathrm{min})$ for $15 \mathrm{~min}$. Finally, $\mathrm{NH}_{3}$-TPD experiment was carried out by increasing the temperature from $100{ }^{\circ} \mathrm{C}$ to $450{ }^{\circ} \mathrm{C}$ (heating rate $\left.10^{\circ} \mathrm{C} / \mathrm{min}\right)$. The desorbed ammonia in the outlet gas was detected using TCD detector. 


\section{Results and Discussion}

The alkaline activation of natural zeolites with the mixed $\mathrm{KOH}$ activator and $\mathrm{Na}-$ water glass and subsequent foaming of the alkaline activated mixture resulted in the formation of inorganic materials which are structurally similar to geopolymers. Due to the gradual decomposition of hydrogen peroxide in a strongly alkaline medium (Equation (1)), the released oxygen caused foaming of the mixture and the formation of macroporous materials. The textural properties of the macroporous materials can be changed by post-synthetic modifications.

$$
2 \mathrm{H}_{2} \mathrm{O}_{2}(\mathrm{l}) \rightarrow 2 \mathrm{H}_{2} \mathrm{O}(\mathrm{l})+\mathrm{O}_{2}(\mathrm{~g})
$$

\subsection{Influence of Acid Leaching}

One of the possibilities of influencing the textural, chemical, and mechanical properties of the samples is leaching with different types of acids under different conditions such as leaching temperature, leaching time or concentration, and the type of the acid. The influence of individual parameters was studied by several characterization techniques and showed advantages and disadvantages of individual procedures.

The chemical composition of samples was determined by X-ray fluorescence (XRF) and is shown in Table 2. It is clear from the results that the concentration, type of the acid, temperature, and the leaching time had a crucial effect on the resulting chemical properties of the modified samples.

Table 2. Chemical composition of acid leached zeolite foam pellets.

\begin{tabular}{|c|c|c|c|c|c|c|c|c|c|c|c|}
\hline \multirow{2}{*}{ Sample } & \multicolumn{8}{|c|}{ Chemical Composition (wt \%) } & \multirow{2}{*}{ SUM } & \multirow{2}{*}{ Si/A1 Ratio } & \multirow{2}{*}{$M_{\mathrm{Si}}$} \\
\hline & $\mathrm{SiO}_{2}$ & $\mathrm{Al}_{2} \mathrm{O}_{3}$ & $\mathrm{~K}_{2} \mathrm{O}$ & $\mathrm{Fe}_{2} \mathrm{O}_{3}$ & $\mathrm{CaO}$ & $\mathrm{Na}_{2} \mathrm{O}$ & $\mathrm{MgO}$ & $\mathrm{TiO}_{2}$ & & & \\
\hline S & 71.20 & 10.50 & 8.71 & 1.37 & 3.25 & 3.84 & 0.72 & 0.16 & 99.75 & 5.75 & 4.96 \\
\hline $80 / 6 / 0.1$ & 78.60 & 11.20 & 5.36 & 1.40 & 1.88 & 0.56 & 0.55 & 0.19 & 99.74 & 5.95 & 10.73 \\
\hline $80 / 6 / 0.5$ & 83.20 & 10.10 & 3.50 & 1.20 & 0.91 & 0.40 & 0.43 & 0.19 & 99.93 & 6.99 & 17.76 \\
\hline $80 / 6 / 1$ & 85.00 & 9.71 & 2.38 & 1.10 & 0.79 & 0.34 & 0.45 & 0.19 & 99.96 & 7.43 & 22.50 \\
\hline $80 / 6 / 2$ & 86.50 & 9.04 & 1.68 & 1.04 & 0.72 & 0.31 & 0.43 & 0.18 & 99.90 & 8.12 & 27.29 \\
\hline $80 / 6 / 3$ & 89.50 & 6.84 & 1.26 & 0.95 & 0.62 & 0.25 & 0.33 & 0.19 & 99.93 & 11.10 & 35.09 \\
\hline $80 / 6 / 6$ & 92.60 & 4.12 & 1.06 & 0.85 & 0.55 & 0.29 & 0.21 & 0.20 & 99.88 & 19.07 & 42.48 \\
\hline $0.1 \mathrm{M}+3 \mathrm{M}$ & 88.20 & 7.54 & 1.55 & 1.10 & 0.71 & 0.23 & 0.34 & 0.22 & 99.89 & 9.93 & 30.54 \\
\hline $40 / 6 / 3$ & 83.30 & 11.00 & 2.22 & 1.40 & 0.91 & 0.29 & 0.57 & 0.19 & 99.87 & 6.43 & 20.62 \\
\hline $60 / 6 / 3$ & 86.30 & 9.10 & 1.61 & 1.20 & 0.77 & 0.30 & 0.47 & 0.20 & 99.94 & 8.05 & 26.22 \\
\hline $80 / 1 / 3$ & 85.20 & 9.46 & 2.20 & 1.26 & 0.78 & 0.30 & 0.47 & 0.21 & 99.87 & 7.64 & 23.07 \\
\hline $80 / 2 / 3$ & 87.30 & 8.24 & 1.66 & 1.14 & 0.72 & 0.28 & 0.42 & 0.20 & 99.96 & 8.99 & 27.66 \\
\hline $80 / 3 / 3$ & 87.30 & 8.35 & 1.52 & 1.11 & 0.71 & 0.29 & 0.40 & 0.21 & 99.88 & 8.87 & 28.93 \\
\hline $\mathrm{H}_{3} \mathrm{PO}_{4}$ & 79.90 & 10.80 & 5.18 & 1.06 & 1.19 & 0.55 & 0.46 & 0.19 & 99.86 & 6.28 & 12.89 \\
\hline $\mathrm{H}_{2} \mathrm{SO}_{4}$ & 84.10 & 9.42 & 2.73 & 1.16 & 0.91 & 0.34 & 0.42 & 0.19 & 99.80 & 7.58 & 20.51 \\
\hline $\mathrm{HNO}_{3}$ & 84.20 & 9.64 & 2.93 & 1.33 & 0.79 & 0.36 & 0.43 & 0.21 & 99.90 & 7.41 & 20.00 \\
\hline TART & 79.00 & 11.40 & 5.50 & 1.30 & 1.35 & 0.63 & 0.48 & 0.19 & 99.86 & 5.88 & 11.66 \\
\hline OXAL & 85.00 & 5.95 & 2.97 & 1.12 & 3.86 & 0.41 & 0.31 & 0.22 & 99.85 & 12.12 & 11.62 \\
\hline CITR & 79.00 & 11.30 & 5.43 & 1.29 & 1.43 & 0.66 & 0.51 & 0.18 & 99.80 & 5.93 & 11.49 \\
\hline
\end{tabular}

The degree of removal of other elements from the material is expressed by the modified silicate modulus $\left(M_{\mathrm{Si}}\right)$ (Equation (2)).

$$
M_{S i}=\frac{\mathrm{SiO}_{2}}{\sum M e_{x} \mathrm{O}}, \mathrm{Me}=\mathrm{Na}, \mathrm{K}, \mathrm{Fe}, \mathrm{Ca}, \mathrm{Mg}(\mathrm{mol} / \mathrm{mol})
$$

The results in Table 2 show that increasing temperature, leaching time, and concentration of hydrochloric acid increased the number of extracted components from the zeolite foam. The extracted components were indicated by the $M_{\mathrm{Si}}$ parameter and by the Si/Al molar ratio which increased from the original value of 4.96 to 19.07 using $6 \mathrm{M} \mathrm{HCl}$. The use of varying concentrations of $\mathrm{HCl}$ showed that if weakly concentrated $\mathrm{HCl}$ (up to $0.5 \mathrm{M}$ ) is used, only free alkali, especially sodium 
and potassium, supplied in the alkaline activator, were neutralized. All other elements $(\mathrm{Ca}, \mathrm{Fe}, \mathrm{Al}$, $\mathrm{Mg}$ ), including potassium contained in the Klinofeed ${ }^{\circledR}$ feedstock, were removed with the use of stronger acids. The influence of leaching time and the temperature was not significant. Using $3 \mathrm{M}$ $\mathrm{HCl}$, the $M_{\mathrm{Si}}$ parameter sharply increased from the original value of 4.96 to 23.07 after the first hour of leaching (Table 2). The increase in the $M_{\mathrm{Si}}$ parameter indicated that $\mathrm{Na}$ and $\mathrm{K}$ were easily and rapidly leached from the material and the process resulted in the removal of most of sodium and potassium. The $\mathrm{Si} / \mathrm{Al}$ ratio was raised by about $\frac{1}{2}$. During the next leaching, a gradual decrease in the content of all elements was observed. The similar trend was observed when the leaching temperature was changed. At temperatures of $40{ }^{\circ} \mathrm{C}$ and $60{ }^{\circ} \mathrm{C}$ only $\mathrm{Na}$ and $\mathrm{K}$ were removed. A more significant decrease in other elements, especially $\mathrm{Al}$ and $\mathrm{Fe}$, was observed only at $80^{\circ} \mathrm{C}$. During acid leaching, a material loss occurred. While leaching, $0.1 \mathrm{M} \mathrm{HCl}$ eliminated approximately $10 \mathrm{wt} \%$ of the material. When using more concentrated acid, the decrease was not so significant, e.g., when using $3 \mathrm{M} \mathrm{HCl}$, the decrease was only $13 \mathrm{wt} \%$. It follows that the excess alkaline activator ( $\mathrm{Na}$ and $\mathrm{K}$ silicates and hydroxides) was removed before the zeolite matrix itself was leached. With the increasing temperature the removing of other elements began, and the $M_{\mathrm{si}}$ parameter and the $\mathrm{Si} / \mathrm{Al}$ ratio gradually increased. Leaching with $3 \mathrm{M} \mathrm{HCl}$ at $60^{\circ} \mathrm{C}$ for $6 \mathrm{~h}$ had a very similar effect to leaching at $80^{\circ} \mathrm{C}$ for $2 \mathrm{~h}$. There were no distinct differences in the chemical composition when using two-step leaching compared to the use of $3 \mathrm{M} \mathrm{HCl}$. However, the differences were particularly evident in textural properties. Hydrochloric acid has been chosen for foam leaching tests because of its ability to remove iron from the samples. For comparison, tests with other mineral and simple organic acids were also performed at the initial concentration of $1 \mathrm{M}$. From the point of view of the chemical composition, it can be seen that the mineral acids $\mathrm{H}_{2} \mathrm{SO}_{4}$ and $\mathrm{HNO}_{3}$ gave similar results in terms of $\mathrm{Si} / \mathrm{Al}$ ratio, but a lesser $\mathrm{K}$ and $\mathrm{Fe}$ removal effect was observed. Weak acids only neutralized free alkalis from alkaline activator and $\mathrm{H}_{3} \mathrm{PO}_{4}$ also partly removed calcium (Table 2). The use of $\mathrm{H}_{2} \mathrm{SO}_{4}$ and $\mathrm{H}_{3} \mathrm{PO}_{4}$ resulted in the zeolite foam contaminated with sulphur (in the form of sulphates) or phosphorus (in the form of phosphates). The contamination by sulphur and phosphate is undesirable for most possible catalytic and sorption applications. The samples additionally contained $0.21 \mathrm{wt} \% \mathrm{~S}$ or $0.23 \mathrm{wt} \% \mathrm{P}$.

The organic acids such as CITR and TART had a very similar effect to $\mathrm{H}_{3} \mathrm{PO}_{4}$ (Table 2). The oxalic acid was the most effective for the removal of aluminium. The removal of aluminium was evident in the $\mathrm{Si} / \mathrm{Al}$ ratio which increased from 7.43 to 12.12 compared to the sample leached with $1 \mathrm{M} \mathrm{HCl}$. The $M_{\mathrm{Si}}$ parameter was only 11.62 in the sample which was due to a lower rate of potassium and especially of calcium elimination. Calcium forms a water-insoluble Ca-oxalate by reaction with oxalic acid which remains trapped in the pores of the aluminosilicate foam and blocks their further purification.

The crystalline structure specified by X-Ray powder diffraction (XRD) showed clinoptilolite as the main crystalline phase with typical reflections at $2 \theta 9.9^{\circ}, 11.2^{\circ}, 17.5^{\circ}$, and $22.4^{\circ}$. The XRD also showed other minor components that belong to mineralogical groups of clays, feldspar, and mica (Figure 2). The crystallinity decreased with increasing leaching time, temperature, and concentration of acid during leaching. However, the powder diffraction patterns show that the basic zeolite structure always remained. The exception was the samples leached using $6 \mathrm{M} \mathrm{HCl}$ where a collapse of the zeolite structure occurred, and the powder diffraction pattern displayed only a reflection of quartz and accompanying minerals (Figure 2a). The comparison of the sample's crystallinity with the original natural zeolite showed that a decrease (approximately $40 \%$ ) of crystallinity $\left(2 \theta 9.9^{\circ},[020]\right)$, due to the alkaline activation occurred. On the other hand, the alkaline activation simultaneously increased the intensity of the second most significant reflection $\left(2 \theta\right.$ reflection $\left.11.2^{\circ},[200]\right)$ because of the higher electron density in the crystal plane. The higher electron density was caused by the presence of sodium and potassium cations. The relative ratio of these two reflections $\left(2 \theta 11.2^{\circ} / 9.9^{\circ}\right)$ was 0.4 (PDF 83-1261) for clinoptilolite. The ratio increased to 0.9 in case of zeolite foam (sample "S"), and gradually decreased to the original value 0.4 to 0.5 with increasing concentration of leaching acid. This value was achieved using the concertation higher than $2 \mathrm{M} \mathrm{HCl}$. The decrease was visible in the results of the XRF analysis and the Na and $\mathrm{K}$ content decreased with increasing acid concentration. There 
was an increase in crystallinity using low concentration acid ( $0.1 \mathrm{M}$ to $1 \mathrm{M})$, compared to sample "S" (Figure 2a). The increase of crystallinity is related to the removal of amorphous structures formed from excess of alkaline activator (sodium and potassium silicates) on the surface of formed zeolite foam.
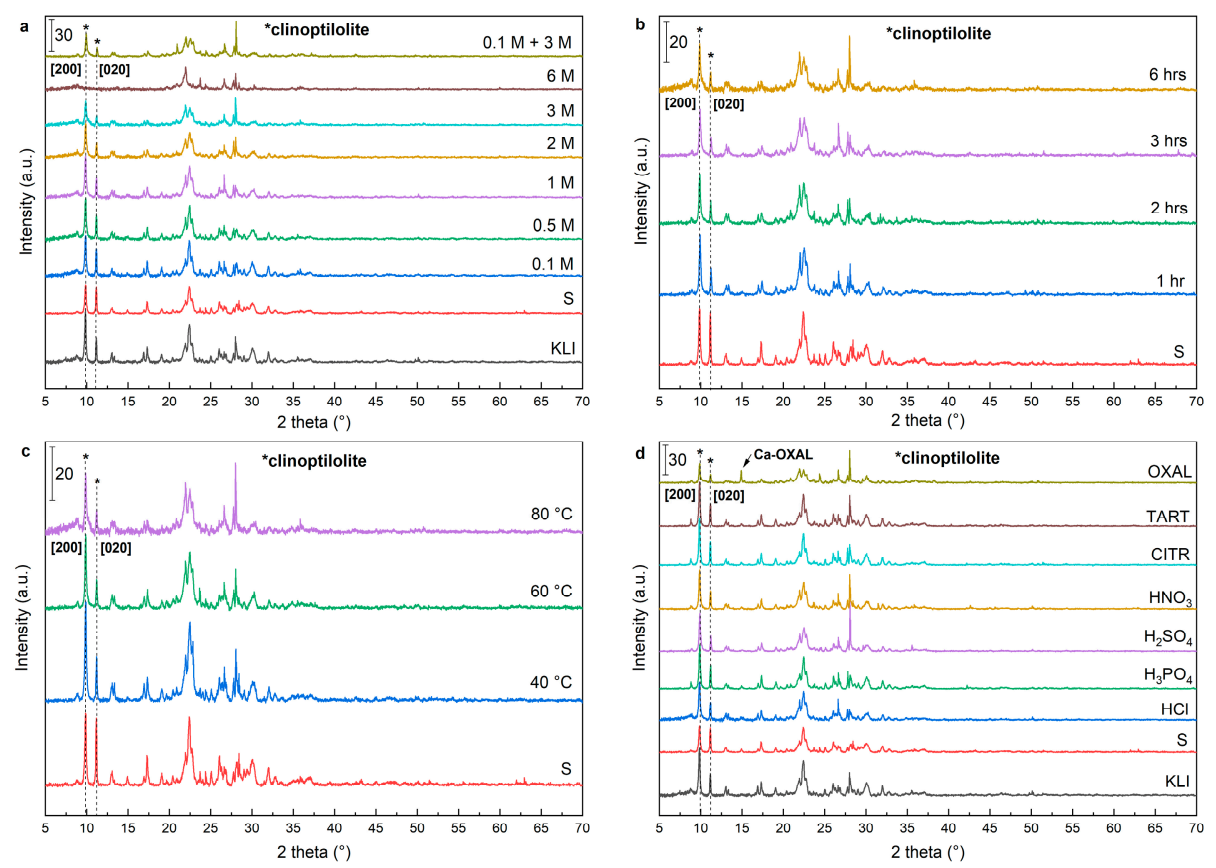

Figure 2. Powder diffraction patterns of modified foams: Influence of acid concentration (a), time (b), temperature (c), and type of acid (d).

A similar effect was observed using $3 \mathrm{M} \mathrm{HCl}$ at leaching temperature of $40{ }^{\circ} \mathrm{C}$ (Figure 2c). The leaching time did not have a significant effect on the crystallinity and the values of the crystallinity were almost constant after $1 \mathrm{~h}$ (Figure $2 \mathrm{~b}$ ). The use of other acids did not have a substantial effect on the crystalline structure. A significant decrease was observed only with the use of oxalic acid. The decrease of crystallinity was associated with a high increase of Si/Al ratio and thereby disruption of the zeolite structure. There were significant intensities at $2 \theta 14.9^{\circ}, 24.3^{\circ}$, and $30.1^{\circ}$ pertaining to Ca-oxalate, in the XRD patterns of OXAL sample which was formed by leaching calcium from the zeolite structure (Figure $2 \mathrm{~d}$ ).

The DRIFT method, which was used to determine the sample structure, showed only small differences between the natural zeolite and the prepared foam samples (Figure 3). Bands characteristic for aluminosilicates and alkali-activated materials are visible in the DRIFT spectra [19-23]. In the measured spectra, there was a typical broadband $\left(3400-3700 \mathrm{~cm}^{-1}\right)$ related to the stretching vibration of bridged hydroxyl groups (Si-OH) in zeolite channels [24]. The intensity of this broadband increased with increasing acid concentration, leaching time, and temperature (Figure $3 \mathrm{a}-\mathrm{c}$ ) due to the increase in $\mathrm{OH}$ groups content. The increase in the amount of $-\mathrm{OH}$ groups was because of acid leaching and the formation of new silanol and aluminol sites (nests). In the case of the use of other mineral and organic acids with a concentration of $1 \mathrm{M}$, the differences in the band intensity were not significant (Figure 3d). The band around $1600 \mathrm{~cm}^{-1}$ corresponded to vibration of $-\mathrm{OH}$ groups in water. Band $470 \mathrm{~cm}^{-1}$ belonged to the Si-O-Si bending vibrations. The Sample "S" showed the vibrations of carbonates produced by air-ageing of foam (880 and 1420-1460 $\mathrm{cm}^{-1}$ ). 

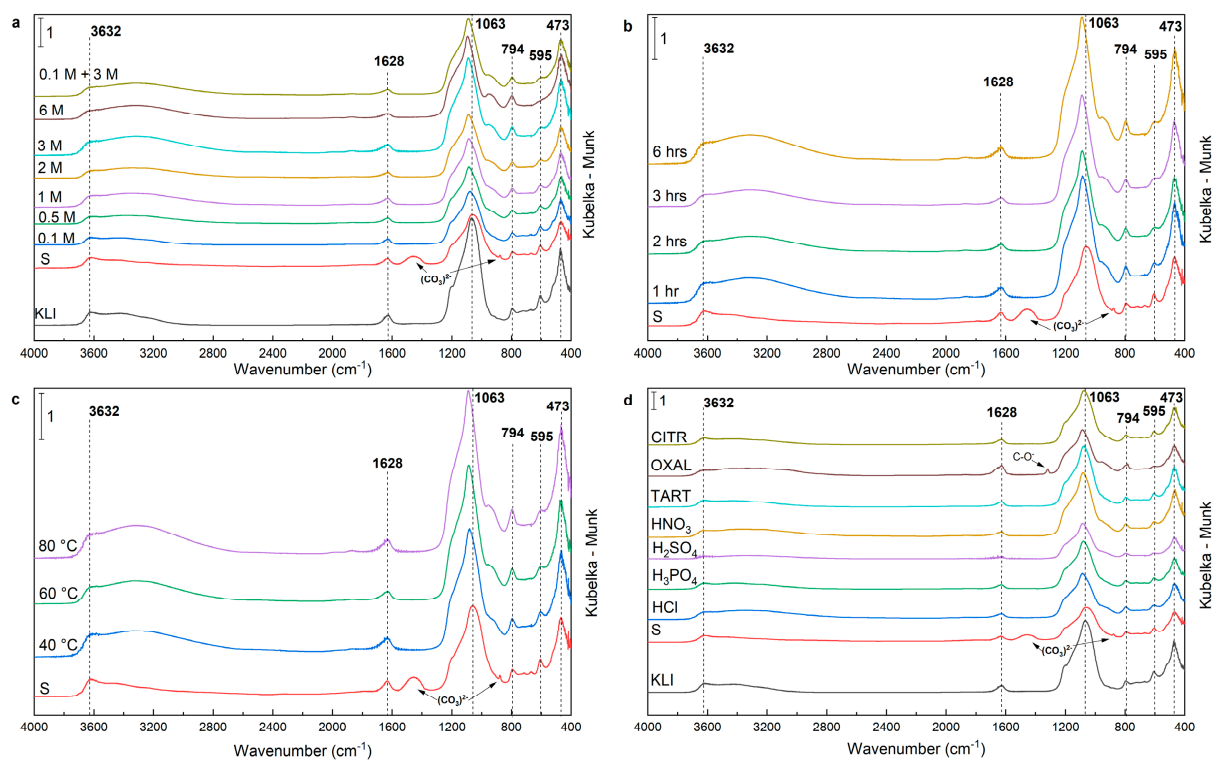

Figure 3. DRIFT spectra of modified foams: Influence of acid concentration (a), time (b), temperature (c), and type of acid (d).

The main band of aluminosilicate materials was located at $850-1300 \mathrm{~cm}^{-1}$ and was related to the asymmetric stretching vibrations of the $\mathrm{Si}-\mathrm{O}-\mathrm{T}$ group $(T=\mathrm{Si}$ or $\mathrm{Al})$ that were formed by tetrahedral units $\left[\mathrm{SiO}_{4}\right]$ and $\left[\mathrm{AlO}_{4}\right]^{-}$of a zeolite and geopolymer network. The band around $1060-1090 \mathrm{~cm}^{-1}$ was attributed to the asymmetric stretching of $\mathrm{Si}-\mathrm{O}-\mathrm{Al}$ and $\mathrm{Si}-\mathrm{O}-\mathrm{Si}$ bonds in the natural zeolite (Klinofeed ${ }^{\circledR}$ ). The location of the main band was almost the same for natural zeolites and alkaline-activated zeolite foams (S). This suggested that there are no structural changes in the zeolite after alkaline activation. Acid leaching caused the shift of the band to $1090 \mathrm{~cm}^{-1}$ (Figure 4a). The band shift is related to the loss of aluminium in the structure, the change in the $\mathrm{Si}-\mathrm{O}-\mathrm{Si}$ angle and the change in the strength of the bends $[9,21]$. The band observed around $1200 \mathrm{~cm}^{-1}$ can be related to external vibrations of the $\mathrm{TO}_{4}$ tetrahedron [25]. The reduction of this band was observed using more than $0.5 \mathrm{M} \mathrm{HCl}$ (Figure 3a). The high-frequency shoulder of the clinoptilolite band complex can be also assigned to vibrations between $\mathrm{Si}-\mathrm{O}(\mathrm{Si})$ neighbours [26]. Our results of acid leaching showed that the band around $1200 \mathrm{~cm}^{-1}$ was related to vibrations between $\mathrm{Si}-\mathrm{O}(\mathrm{Si})$ neighbours, due to the increase in the intensity of this band during acid leaching. With the increasing acid concentration, the amount of leached aluminium and the intensity of this band increased (Figure 3a).

The intensity of these bands increased in the same manner as the silanol band. Two bands of different vibrations of $\mathrm{Al}-\mathrm{O}-\mathrm{Si}\left(800 \mathrm{~cm}^{-1}\right.$ bending vibrations, $610 \mathrm{~cm}^{-1}$ stretching vibrations) were noticeable in the spectra. The intensity of the band around $800 \mathrm{~cm}^{-1}$, its intensity did not change much during post-synthesis treatments, however the band intensity of $610 \mathrm{~cm}^{-1}$ decreased with increasing $\mathrm{HCl}$ concentration (Figure 3a). This was the effect of dissolution of aluminium from foams. The loss was not observed after leaching with diluted $\mathrm{HCl}$. In the case of the OXAL sample, the band of $1330 \mathrm{~cm}^{-1}$ apparently belongs to the vibrations of $\mathrm{C}-\mathrm{O}-$ present in the calcium oxalate formed by leaching the sample using $1 \mathrm{M}$ oxalic acid [27].

The deconvolution of the peaks in the wavenumber range of $850-1350 \mathrm{~cm}^{-1}$ (Figure 4a) showed a band shift corresponding to asymmetric vibrations of the $\mathrm{Si}-\mathrm{O}-\mathrm{T}$ groups. The band shift was from the original value of $1060\left(1057 \mathrm{~cm}^{-1}\right)$ to $1080-1092 \mathrm{~cm}^{-1}$ depending on the concentration of acid, for sample "S". This shift corresponded to the loss of aluminium from the matrix (reduction of Si-O-Al units). At the same time the intensity of the band $1210-1215 \mathrm{~cm}^{-1}$ increased. For sample "S", this band was shifted to $1203 \mathrm{~cm}^{-1}$. The shift was related to the structural disruption due to alkaline activation, and the surface covering with amorphous components of the unreacted alkaline activator. 

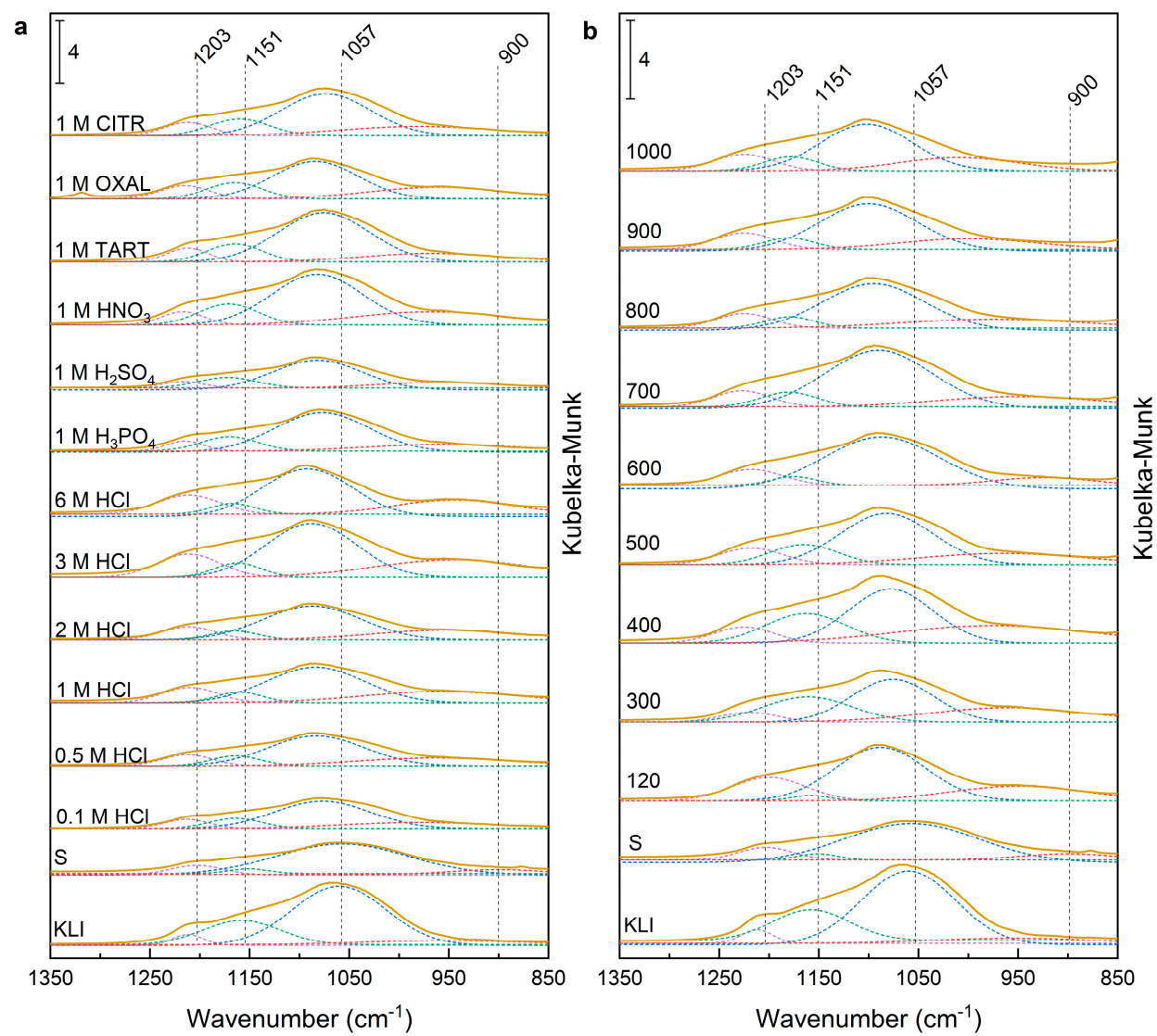

Figure 4. Deconvolution of the main band of DRIFT spectra in the range $850-1350 \mathrm{~cm}^{-1}$ for acid leached zeolite foams (a) and for calcined zeolite foams (b). Deconvolution curves: Measured curve (yellow), 1st deconvolution peak (violet), 2nd deconvolution peak (green), 3rd deconvolution peak (blue), 4th deconvolution peak (red).

The comparison of the effect of leaching using $1 \mathrm{M}$ acids showed only slight differences in the band displacement. The band was shifted from 1060 to $1073-1077 \mathrm{~cm}^{-1}$ for weak acids (organic acids-TATR, CITR, and mineral acids- $\mathrm{H}_{3} \mathrm{PO}_{4}$ ). Strong mineral acids and OXAL moved the band to $1082-1085 \mathrm{~cm}^{-1}$. The shift was proportional to the aluminium content of a sample (Table 2). The band about $1215 \mathrm{~cm}^{-1}$ was most intensive using $1 \mathrm{M} \mathrm{HCl}$ (Figure 4a). $\mathrm{HCl}$ is the most efficient acid for removing other elements ( $\mathrm{Al}, \mathrm{Na}, \mathrm{K}, \mathrm{Fe}, \mathrm{Mg}$ ) during acid leaching that had $\mathrm{HCl}$. This effect was demonstrated by the $M_{\mathrm{Si}}$ parameter (Table 2) and was also observed directly during sample preparation at different colour intensity of the mother liquor.

The textural properties were studied by $\mathrm{N}_{2}$ physisorption and macroporous structure also by mercury porosimetry. The mercury porosimetry showed a relatively large dispersion of total intrusion volume due to macroporous inhomogeneity of individual samples, and also some measurement error caused by the presence of macropores (hundreds of micrometres). As previously published in the article [3], the material mainly contains four pore size groups. These four groups include micropores with a size up to $2 \mathrm{~nm}$, mesopores transitioning smoothly into macropores with size up to $150 \mathrm{~nm}$, as well as macropores of characteristic size hundreds of nm up to $1 \mu \mathrm{m}$, and "supermacropores" with a typical size of tens to hundreds of micrometres. While the natural zeolite Klinofeed ${ }^{\circledR}$ had a small specific surface area and contained only mesopores, a detailed evaluation of the $\mathrm{N}_{2}$ physisorption data of the leached samples (Table 3) showed a significant increase in the total specific surface area and pore volume, depending on the increase of acid leaching concentration. The increase of surface area was caused by cleaning and purifying the micropores present in the zeolite and binder matrix. The specific surface area increased from $6 \mathrm{~m}^{2} / \mathrm{g}$ for the sample "S" to $282 \mathrm{~m}^{2} / \mathrm{g}$ for the sample leached using $3 \mathrm{M}$ 
$\mathrm{HCl}$, and almost $350 \mathrm{~m}^{2} / \mathrm{g}$ for the sample leached in two-step leaching using $0.1 \mathrm{M}$ and $3 \mathrm{M} \mathrm{HCl}$ (Table 3). The same trend was observed in the total pore volume where larger volume of micropores was obtained when acid with the concentration above $0.5 \mathrm{M}$ was used. First, wide micropores were leached (size about $1 \mathrm{~nm}$ ) but differentiation to micropores with a characteristic size from 0.8 to $0.9 \mathrm{~nm}$, 1.0 to $1.1 \mathrm{~nm}$, and micropores from $1.3 \mathrm{~nm}$ to $1.5 \mathrm{~nm}$ were evident when using acid with concentration higher than $1 \mathrm{M}$ (Figure 5a). When a sample was leached with $6 \mathrm{M} \mathrm{HCl}$, the zeolite structure was disrupted, which was accompanied by the decrease in specific surface area, but also in the distribution of micropores where the collapse of individual types of micropores was distinct and their merging into wide micropores (size from $1.0 \mathrm{~nm}$ to $1.5 \mathrm{~nm}$ ).

Table 3. Mechanical and textural properties of acid leached zeolite foam pellets.

\begin{tabular}{|c|c|c|c|c|c|c|}
\hline Sample & $\begin{array}{c}\text { Density } \\
\left(\mathrm{cm}^{3} / \mathrm{g}\right)^{*}\end{array}$ & $\begin{array}{l}\text { Cutting Edge } \\
\text { Strength (N) }\end{array}$ & $\begin{array}{c}\text { Specific } \\
\text { Surface } \\
\text { Area }\left(\mathrm{m}^{2} / \mathrm{g}\right)\end{array}$ & $\begin{array}{l}\text { Total Pore } \\
\text { Volume } \\
\left(\mathrm{cm}^{3} / \mathrm{g}\right)\end{array}$ & $\begin{array}{c}\text { Micropore } \\
\text { Volume } \\
\left(\mathrm{cm}^{3} / \mathrm{g}\right)\end{array}$ & $\begin{array}{l}\text { Mesopore } \\
\text { Volume } \\
\left(\mathrm{cm}^{3} / \mathrm{g}\right)\end{array}$ \\
\hline KLI & - & - & 24.6 & 0.062 & 0.005 & 0.055 \\
\hline$S$ & 1.08 & 96.5 & 6.0 & 0.029 & 0.000 & 0.024 \\
\hline $80 / 6 / 0.1$ & 0.96 & 23.3 & 96.7 & 0.076 & 0.014 & 0.055 \\
\hline $80 / 6 / 0.5$ & 0.89 & 21.3 & 119.2 & 0.091 & 0.023 & 0.061 \\
\hline $80 / 6 / 1$ & 0.89 & 22.7 & 160.2 & 0.093 & 0.032 & 0.056 \\
\hline $80 / 6 / 2$ & 0.87 & 19.7 & 268.8 & 0.117 & 0.052 & 0.061 \\
\hline $80 / 6 / 3$ & 0.86 & 22.1 & 281.9 & 0.128 & 0.057 & 0.065 \\
\hline $80 / 6 / 6$ & 0.82 & 20.2 & 166.6 & 0.110 & 0.035 & 0.068 \\
\hline $0.1 \mathrm{M}+3 \mathrm{M}$ & 0.85 & 17.3 & 346.8 & 0.152 & 0.060 & 0.086 \\
\hline $40 / 6 / 3$ & 0.90 & 27.6 & 24.8 & 0.045 & 0.004 & 0.035 \\
\hline $60 / 6 / 3$ & 0.86 & 23.4 & 103.1 & 0.100 & 0.016 & 0.077 \\
\hline $80 / 1 / 3$ & 0.87 & 21.4 & 99.2 & 0.082 & 0.018 & 0.059 \\
\hline $80 / 2 / 3$ & 0.85 & 27.7 & 238.9 & 0.110 & 0.052 & 0.052 \\
\hline $80 / 3 / 3$ & 0.90 & 23.4 & 278.4 & 0.122 & 0.052 & 0.065 \\
\hline $\mathrm{H}_{3} \mathrm{PO}_{4}$ & 0.88 & 14.0 & 32.9 & 0.042 & 0.006 & 0.030 \\
\hline $\mathrm{H}_{2} \mathrm{SO}_{4}$ & 0.80 & 19.4 & 95.4 & 0.081 & 0.017 & 0.055 \\
\hline $\mathrm{HNO}_{3}$ & 0.88 & 11.0 & 102.6 & 0.070 & 0.021 & 0.041 \\
\hline TART & 0.88 & 16.2 & 23.6 & 0.040 & 0.004 & 0.029 \\
\hline OXAL & 0.86 & 15.1 & 252.5 & 0.133 & 0.040 & 0.085 \\
\hline CITR & 0.80 & 10.6 & 42.3 & 0.065 & 0.001 & 0.058 \\
\hline
\end{tabular}

* average values from five measured samples; ** average values from 10 measured samples.

The better cleaning of pores was achieved with increasing the leaching time using $3 \mathrm{M} \mathrm{HCl}$ (Figure 5b). The samples leached with $3 \mathrm{M} \mathrm{HCl}$ at $40{ }^{\circ} \mathrm{C}$ did not contain any micropores. Moreover, there was no significant cleaning of pores at $60^{\circ} \mathrm{C}$ and the structure was similar to a sample leached using $0.5 \mathrm{M} \mathrm{HCl}$ (Figure $5 \mathrm{c}$ ). The results for other acids indicated that only oxalic acid was able to remove the micropores even though they are partially blocked by insoluble Ca-oxalate. The OXAL sample had a microporous structure with well-purified micropores but with a less sharp distribution of micropores than with $\mathrm{HCl}$. Partial purification was achieved also with $1 \mathrm{M} \mathrm{HNO}_{3}$ and $1 \mathrm{M} \mathrm{H}_{2} \mathrm{SO}_{4}$. Other acids did not affect the microporous structure (Figure $5 \mathrm{~d}$ ).

When leaching using different concentration of acids, the volume of mesopores increased two or three times compared to the original sample " $\mathrm{S}$ " and was not significantly dependent on the concentration of the acid (Table 3). The exception was the sample " $0.1 \mathrm{M}+3 \mathrm{M}$ " prepared by two-step leaching using 0.1 and $3 \mathrm{M} \mathrm{HCl}$, and later used to determine the effect of calcination. Another exception was the OXAL sample leached using $1 \mathrm{M}$ oxalic acid where the increase in mesopore volume was almost four times higher. The increase of the pore volume and the total surface area was similar when using different temperatures and leaching times. It was evident from the measured values of samples leached with different acids (except OXAL) that these samples had lower specific surface area and pore volume than the sample leached with $1 \mathrm{M} \mathrm{HCl}$. Our results showed that $\mathrm{HCl}$ is the most suitable for post-synthesis treatments. Oxalic acid was better than $\mathrm{HCl}$ in terms of textural parameters than $\mathrm{HCl}$ 
but due to the rapid decrease in aluminium content, the zeolite structure was partially collapsed under selected conditions.
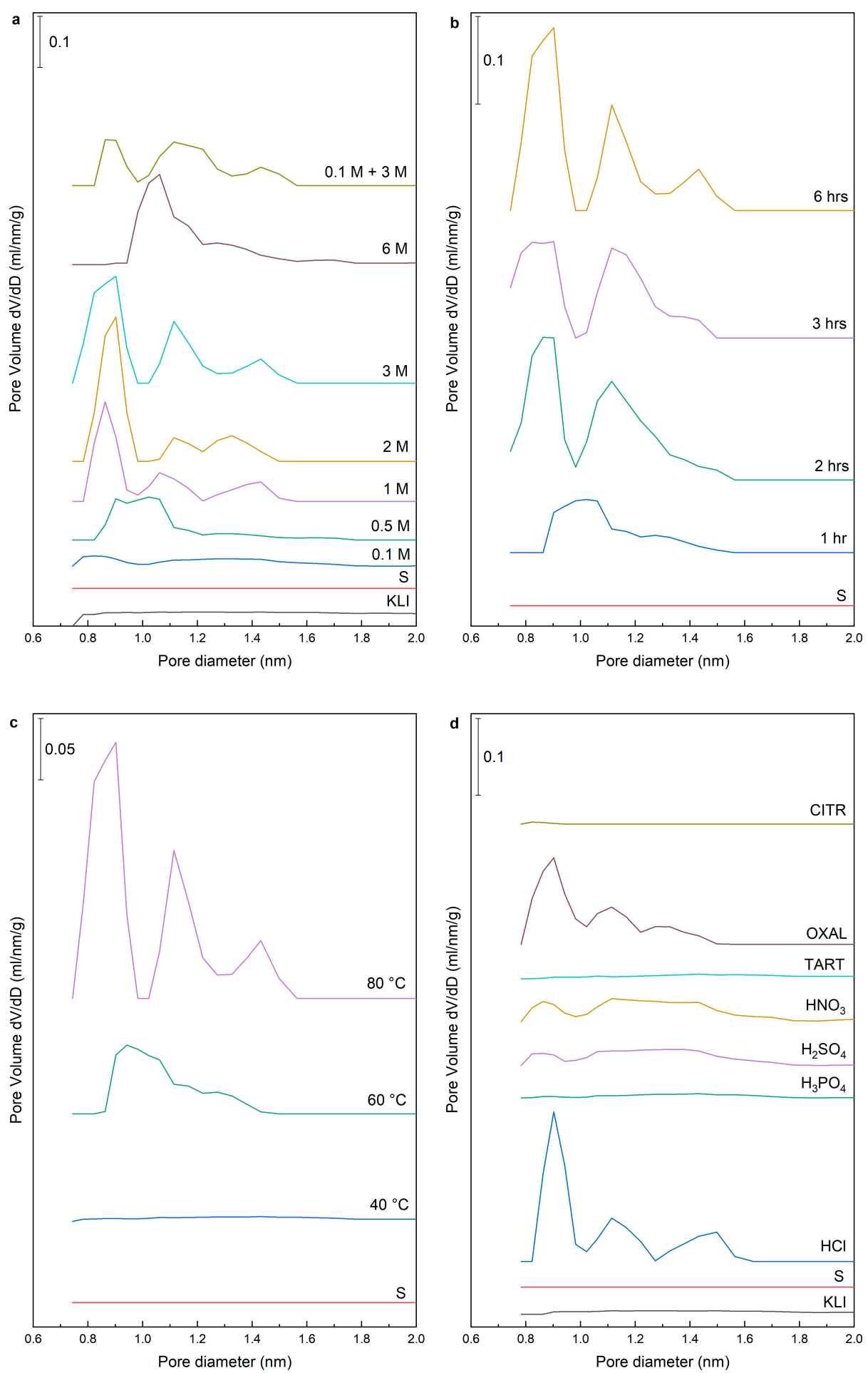

Figure 5. Micropore distribution of modified foams: Influence of acid concentration (a), time (b), temperature (c), and type of acid (d).

The leaching temperature, similar to the concentration of an acid used, had a significant effect on the change in the texture of the materials Leaching at $40{ }^{\circ} \mathrm{C}$ partially increased porosity by cleaning the mesopores (Table 3). At $60^{\circ} \mathrm{C}$, an increase in the micropore volume was observed, the volume of 
mesopores increased twice and the surface area increased four times. At $80^{\circ} \mathrm{C}$, a significant increase in all parameters was observed. The specific surface area and the micropore volume increased up to three times compared to leaching at $60^{\circ} \mathrm{C}$, the volume of mesopores did not change much. The results obtained with various leaching times using $3 \mathrm{M} \mathrm{HCl}$ showed that the mesopores were cleaned in the first $\mathrm{h}$ of leaching and micropores were cleaned in the second $\mathrm{h}$ of leaching. Leaching using $3 \mathrm{M} \mathrm{HCl}$ for $1 \mathrm{~h}$ has a very similar effect to leaching using $0.1 \mathrm{M} \mathrm{HCl}$ for $6 \mathrm{~h}$.

From the point of view of the mechanical properties of samples (Table 3), there was a noticeable decrease in volume density in contrast to the changes in specific surface area and pore volume. The increasing acid concentration, leaching time, and temperature reduced volume density from 1.08 to $0.8 \mathrm{~cm}^{3} / \mathrm{g}$. This decrease was related to the removal of the excess alkaline activator in the pores, which strengthened the material. As the data obtained by cutting edge strength measurements in Table 3 show, the strength of the material decreased significantly after the removal of this excess alkaline activator. However, with changing leaching conditions (acid concentration, temperature, or leaching time) the pellet strengths were almost identical and showed very low dispersion due to a measurement error. When leaching at different concentrations of $\mathrm{HCl}$ and at different temperatures, only the sample leached using $0.1 \mathrm{M} \mathrm{HCl}$ and a sample leached at $40{ }^{\circ} \mathrm{C}$ showed a higher strength than the others. This increase was due to residual (imperfectly removed) activator. The average strength value for a range of acid concentrations used is $21.6 \mathrm{~N}(\mathrm{RSD}=6.6 \%)$ and was therefore 4.5 times lower than for the original sample without leaching. A slight decrease in the strength was observed for the other acids used when compared to $1 \mathrm{M} \mathrm{HCl}$.

The number of acid sites on the surface of acid-modified samples was determined by $\mathrm{NH}_{3}$-TPD. Typically, the TPD curves of the modified samples contain a dominant low-temperature peak with a centre of between 165 and $200{ }^{\circ} \mathrm{C}$. This peak is attributed to the ammonia desorption from the weakly acid Lewis centres (low-acid sites). Acid leaching results to a further and less intense desorption peak at a higher temperature with a maximum of about $470{ }^{\circ} \mathrm{C}$ (strong-acid sites). This desorption peak is usually assigned to ammonia bound at Brønsted acid centres of zeolite and stronger Lewis acid centres [28]. Unfortunately, NH3-TPD does not allow a distinction between Lewis and Brønsted. The quantitative results of the $\mathrm{NH}_{3}$-TPD curves are summarized in Tables 4 and 5.

Table 4. Acidity of zeolite foam pellets modified by $\mathrm{HCl}$, determined by $\mathrm{NH}_{3}$-TPD.

\begin{tabular}{|c|c|c|c|c|c|c|c|}
\hline Sample & $\begin{array}{c}\text { CSUM } \\
(\mathrm{mmol} / \mathrm{g})\end{array}$ & $T_{\max 1}\left({ }^{\circ} \mathrm{C}\right)$ & $\begin{array}{c}\mathrm{c}_{\mathrm{LT}} \\
(\mathrm{mmol} / \mathrm{g})\end{array}$ & $\begin{array}{c}\text { Population } \\
\text { LT (\%) }\end{array}$ & $T_{\max 2}\left({ }^{\circ} \mathrm{C}\right)$ & $\begin{array}{c}\mathrm{c}_{\mathrm{HT}} \\
(\mathrm{mmol} / \mathrm{g})\end{array}$ & $\begin{array}{c}\text { Population } \\
\text { HT (\%) }\end{array}$ \\
\hline$S$ & 0.809 & 171 & 0.809 & 100 & & & \\
\hline $80 / 6 / 0.1$ & 1.182 & 167 & 1.055 & 89 & 298 & 0.127 & 11 \\
\hline $80 / 6 / 0.5$ & 0.968 & 166 & 0.882 & 91 & 327 & 0.086 & 9 \\
\hline $80 / 6 / 1$ & 0.779 & 175 & 0.734 & 94 & 319 & 0.045 & 6 \\
\hline $80 / 6 / 2$ & 0.719 & 173 & 0.680 & 95 & 313 & 0.039 & 5 \\
\hline $80 / 6 / 3$ & 0.493 & 170 & 0.422 & 86 & 293 & 0.071 & 14 \\
\hline $80 / 6 / 6$ & 0.148 & 143 & 0.096 & 65 & 280 & 0.052 & 35 \\
\hline $0.1 \mathrm{M}+3 \mathrm{M}$ & 0.518 & 166 & 0.464 & 90 & 309 & 0.054 & 10 \\
\hline $40 / 6 / 3$ & 0.939 & 178 & 0.892 & 95 & 318 & 0.047 & 5 \\
\hline $60 / 6 / 3$ & 0.712 & 167 & 0.661 & 93 & 312 & 0.051 & 7 \\
\hline $80 / 1 / 3$ & 0.725 & 173 & 0.649 & 90 & 306 & 0.076 & 10 \\
\hline $80 / 2 / 3$ & 0.614 & 162 & 0.576 & 94 & 312 & 0.038 & 6 \\
\hline $80 / 3 / 3$ & 0.581 & 163 & 0.533 & 92 & 313 & 0.048 & 8 \\
\hline
\end{tabular}

CSUM - total concentration of acid sites $(\mathrm{mmol} / \mathrm{g}) ; T_{\max 1}$ - the first temperature maximum $\left({ }^{\circ} \mathrm{C}\right) ; \mathrm{C}_{\mathrm{LT}}$ - $\mathrm{Concentration}$ of low-temperature acid sites $(\mathrm{mmol} / \mathrm{g}) ; T_{\max 2}$ - the second temperature maximum $\left({ }^{\circ} \mathrm{C}\right) ; \mathrm{C}_{\mathrm{HT}}$ - concentration of high-temperature acid sites (mmol/g); LT-low temperature peak (weak acid sites); HT-high temperature peak (strong acid sites). 
Table 5. Acidity of $1 \mathrm{M}$ acids modified zeolite foam pellets determined by the $\mathrm{NH}_{3}$-TPD.

\begin{tabular}{|c|c|c|c|c|c|c|c|}
\hline Sample & $\begin{array}{c}\text { CSUM } \\
(\mathrm{mmol} / \mathrm{g})\end{array}$ & $T_{\max 1}\left({ }^{\circ} \mathrm{C}\right)$ & $\begin{array}{c}\mathrm{c}_{\mathrm{LT}} \\
(\mathrm{mmol} / \mathrm{g})\end{array}$ & $\begin{array}{c}\text { Population } \\
\text { LT (\%) }\end{array}$ & $T_{\max 2}\left({ }^{\circ} \mathrm{C}\right)$ & $\begin{array}{c}\mathrm{c}_{\mathrm{HT}} \\
(\mathrm{mmol} / \mathrm{g})\end{array}$ & $\begin{array}{c}\text { Population } \\
\text { HT (\%) }\end{array}$ \\
\hline$S$ & 0.809 & 171 & 0.809 & 100 & & & 0 \\
\hline $\mathrm{HCl}$ & 0.779 & 175 & 0.734 & 94 & 319 & 0.045 & 6 \\
\hline $\mathrm{HNO}_{3}$ & 0.931 & 169 & 0.876 & 94 & 327 & 0.055 & 6 \\
\hline $\mathrm{H}_{3} \mathrm{PO}_{4}$ & 1.224 & 170 & 1.118 & 91 & 314 & 0.106 & 9 \\
\hline $\mathrm{H}_{2} \mathrm{SO}_{4}$ & 0.891 & 175 & 0.816 & 92 & 318 & 0.075 & 8 \\
\hline OXAL & 0.394 & 153 & 0.369 & 94 & 272 & 0.025 & 6 \\
\hline TART & 1.145 & 175 & 1.007 & 88 & 301 & 0.138 & 12 \\
\hline CITR & 1.144 & 170 & 1.036 & 91 & 297 & 0.108 & 9 \\
\hline
\end{tabular}

The acid leaching $(0.1 \mathrm{M})$ led to an increase in total acidity compared to sample " $\mathrm{S}$ " and centres with a maximum of about $300{ }^{\circ} \mathrm{C}$ were generated (Figure 6a). When leaching using low-concentrated acids, the surface was cleaned from the alkaline activator and $\mathrm{Na}^{+}$and $\mathrm{K}^{+}$ions were removed. There was a partial micropore opening of the zeolite and $\mathrm{N}(\mathrm{K})-\mathrm{A}-\mathrm{S}-\mathrm{H}$ matrixes due to polycondensation of the dissolved aluminosilicates. The matrix had the Lewis sites on the surface which were presented by $\mathrm{Ca}^{2+}, \mathrm{Mg}^{2+}, \mathrm{Al}^{3+}$, and $\mathrm{Fe}^{3+}$ cations. The removal of cations occurred with higher concentration of the leaching acid. The similar effect was by leaching with $0.5 \mathrm{M}$ or $3 \mathrm{M} \mathrm{HCl}$ at the leaching temperature $40{ }^{\circ} \mathrm{C}$ (Figure 6c). With increasing acid concentration, temperature, or leaching time, the number of acid sites gradually decreased. The amount of strong acid sites changed slightly with time and temperature, their population was in the range of $5 \%$ to $14 \%$. The exception was the higher acidity of the sample leached using $6 \mathrm{M} \mathrm{HCl}$, where the zeolite structure was disintegrated, which led to a significant increase in strong acid sites and an increase in their population to 35\% (Tables 4 and 5). The two-step leached material had a slightly higher total amount of acid sites compared to the material leached with $3 \mathrm{M} \mathrm{HCl}$. This is due to more efficient surface cleaning and a higher total surface area.
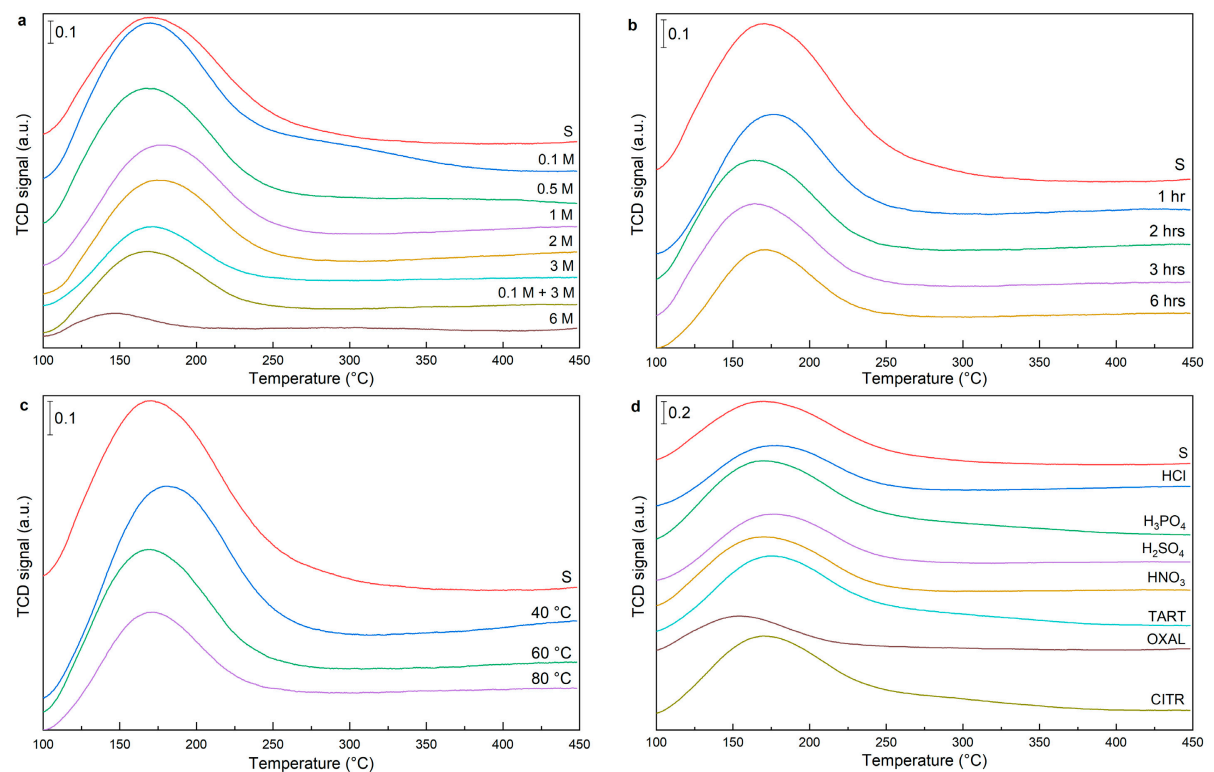

Figure 6. $\mathrm{NH}_{3}$-TPD of acid leached zeolite foams: Influence of acid concentration (a), time (b), temperature (c), and type of acid (d).

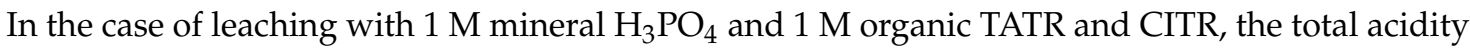
of the material increased compared to $\mathrm{HCl}$ (Table 5). These acids are weak acids and leaching has an effect very similar to leaching with $0.1 \mathrm{M} \mathrm{HCl}$. Mineral acids $\mathrm{H}_{2} \mathrm{SO}_{4}$ and $\mathrm{HNO}_{3}$ had a similar effect to the acidity of the materials as $\mathrm{HCl}$. The most significant difference occurred with oxalic acid, where the 
total acidity was only half than of $\mathrm{HCl}$ (Figure 6d). This low value was due to the efficient removal of octahedral aluminium from the structure of the material that bears Lewis acidity.

\subsection{Influence of Calcination}

To determine the effect of calcination temperature to structural, textural, and mechanical properties, a two-step leached sample with $0.1 \mathrm{M}$ and $3 \mathrm{M} \mathrm{HCl}$ was used. The two-step leached sample showed the best parameters from modified samples. The sample heating was accompanied by the colour change from light green to yellow and then to orange. This change was related to the formation of iron oxides during the calcination of samples (Figure 7).

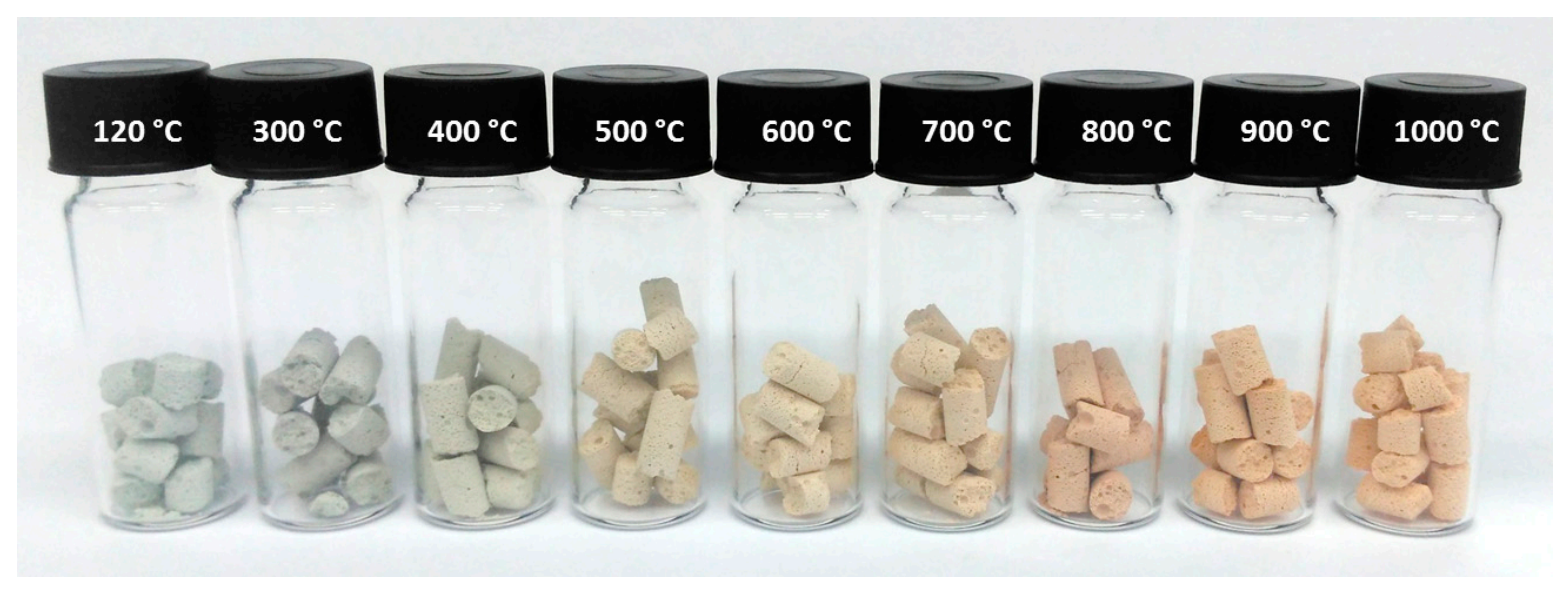

Figure 7. Pictures of the calcined foams.

As stated in the article [3], it is clear from thermogravimetry data that during the heating process freely bound water, water from micropores, and water released from hydroxyls bound in silanol and aluminol groups of the zeolite and $\mathrm{N}(\mathrm{K})-\mathrm{A}-\mathrm{S}-\mathrm{H}$ binder matrix gel gradually escape. This process is terminated at $650{ }^{\circ} \mathrm{C}$. No further weight change occurs at higher temperatures.

$\mathrm{X}$-ray diffraction patterns (Figure 8a) showed that there were changes in the crystal structure of the samples during calcination at $300{ }^{\circ} \mathrm{C}$ to $1000{ }^{\circ} \mathrm{C}$. Diffraction analysis of the samples showed a gradual decrease in the sample crystallinity. The decrease was observed up to $700{ }^{\circ} \mathrm{C}$. At higher temperatures the clinoptilolite phase was removed and only diffraction lines of quartz, crystobalite, albite, and anorthite were visible on the diffractograms.
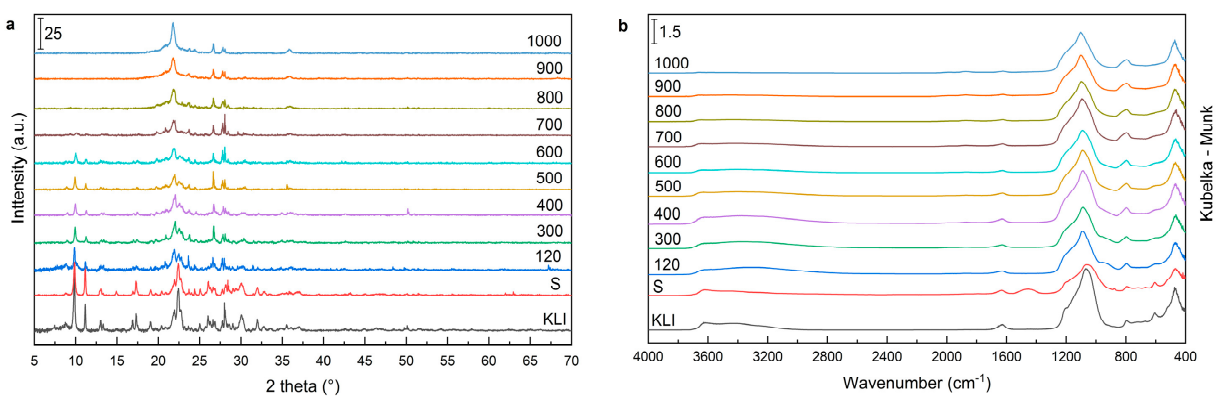

Figure 8. Powder diffraction patterns (a) and DRIFT spectra (b) of calcined foams.

The DRIFT spectra (Figure $8 \mathrm{~b}$ ) showed the same bands as the spectra taken during the leaching experiments. The intensity of the vibration bands of the $\mathrm{OH}$ groups decreased as the temperature increased, typical is broadband $3400-3600 \mathrm{~cm}^{-1}$ (silanol and aluminol groups) and the band at about $1635 \mathrm{~cm}^{-1}$ corresponding to bending vibration of $\mathrm{OH}$ groups of adsorbed water, until these bands were 
gradually disappeared. Typical bands belonging to aluminosilicate materials $850-1350 \mathrm{~cm}^{-1}, 800 \mathrm{~cm}^{-1}$, and $470 \mathrm{~cm}^{-1}$ stayed almost unchanged.

The deconvolution of the band $850-1350 \mathrm{~cm}^{-1}$ (Figure $4 \mathrm{~b}$ ) showed that the main band intensity of $1060-1100 \mathrm{~cm}^{-1}$ did not change much, but compared to the leached samples it moved to $1102 \mathrm{~cm}^{-1}$ at the calcination temperature of $1000{ }^{\circ} \mathrm{C}$. This shift was related to the disintegration of the structure and the formation of silica phases and feldspars (albite, anothite) [29]. In the spectra, there were changes at temperatures of about $600{ }^{\circ} \mathrm{C}$, especially visible for the $1160-1180 \mathrm{~cm}^{-1}$ band, which was vibration-dependent between tetrahedrons and the intensity of the band was constant at this temperature. This suggests that during the thermal stress of samples a certain part of the $\mathrm{Al}$ atoms passes into cationic positions, forming the complex $\mathrm{Al}^{3+}\left(\mathrm{OH}^{-} \ldots \mathrm{H}^{+}\right)$. The complex continues to fall apart when the temperature rises. [30]

From the sample texture point of view (Table 6), the collapse of the microporous structure in samples calcined at temperatures above $600^{\circ} \mathrm{C}$ was obvious. $\mathrm{N}_{2}$ physisorption measurements indicated that micropores are no longer present in the samples (Figure 9a). Similarly, there was a rapid decrease in the specific surface area from nearly 350 to only about $20 \mathrm{~m}^{2} / \mathrm{g}$, mainly due to the disappearance of micropores counted in the total surface area (Table 6). The volume of mesopores did not change too much and decreased slowly. There was also slow growth of density from $600{ }^{\circ} \mathrm{C}$ due to gradual shrinkage of the samples. This phenomenon was related to the gradual increase in the strength of the calcined samples, where the shrinkage led to the strengthening of the porous structure. The porous structure was presented only by the "supermacropores" of inert aluminosilicate ceramic material.

Table 6. Mechanical and textural properties of calcined zeolite foam pellets.

\begin{tabular}{|c|c|c|c|c|c|c|}
\hline $\begin{array}{l}\text { Sample-Calcination } \\
\text { Temperature } \\
\left({ }^{\circ} \mathrm{C}\right)\end{array}$ & $\begin{array}{l}\text { Density } \\
\left(\mathrm{cm}^{3} / \mathrm{g}\right)\end{array}$ & $\begin{array}{l}\text { Cutting } \\
\text { Edge } \\
\text { Strength }(\mathrm{N})\end{array}$ & $\begin{array}{c}\text { Specific } \\
\text { Surface } \\
\text { Area }\left(\mathrm{m}^{2} / \mathrm{g}\right)\end{array}$ & $\begin{array}{l}\text { Total Pore } \\
\text { Volume } \\
\left(\mathrm{cm}^{3} / \mathrm{g}\right)\end{array}$ & $\begin{array}{l}\text { Micropore } \\
\text { Volume } \\
\left(\mathrm{cm}^{3} / \mathrm{g}\right)\end{array}$ & $\begin{array}{c}\text { Mesopore } \\
\text { Volume } \\
\left(\mathrm{cm}^{3} / \mathrm{g}\right)\end{array}$ \\
\hline KLI & - & - & 24.6 & 0.062 & 0.005 & 0.055 \\
\hline$S$ & 1.08 & 96.5 & 6.0 & 0.029 & 0.000 & 0.024 \\
\hline 120 & 0.85 & 17.3 & 346.8 & 0.152 & 0.060 & 0.086 \\
\hline 300 & 0.79 & 10.4 & 199.9 & 0.140 & 0.028 & 0.105 \\
\hline 400 & 0.78 & 9.5 & 151.5 & 0.092 & 0.028 & 0.060 \\
\hline 500 & 0.78 & 12.1 & 88.5 & 0.075 & 0.018 & 0.049 \\
\hline 600 & 0.81 & 11.2 & 40.4 & 0.077 & 0.003 & 0.064 \\
\hline 700 & 0.80 & 12.1 & 26.0 & 0.060 & $<0.001$ & 0.052 \\
\hline 800 & 0.82 & 13.2 & 24.7 & 0.055 & 0.000 & 0.049 \\
\hline 900 & 0.82 & 14.0 & 21.3 & 0.056 & 0.000 & 0.049 \\
\hline 1000 & 0.84 & 14.6 & 14.6 & 0.039 & 0.000 & 0.034 \\
\hline
\end{tabular}
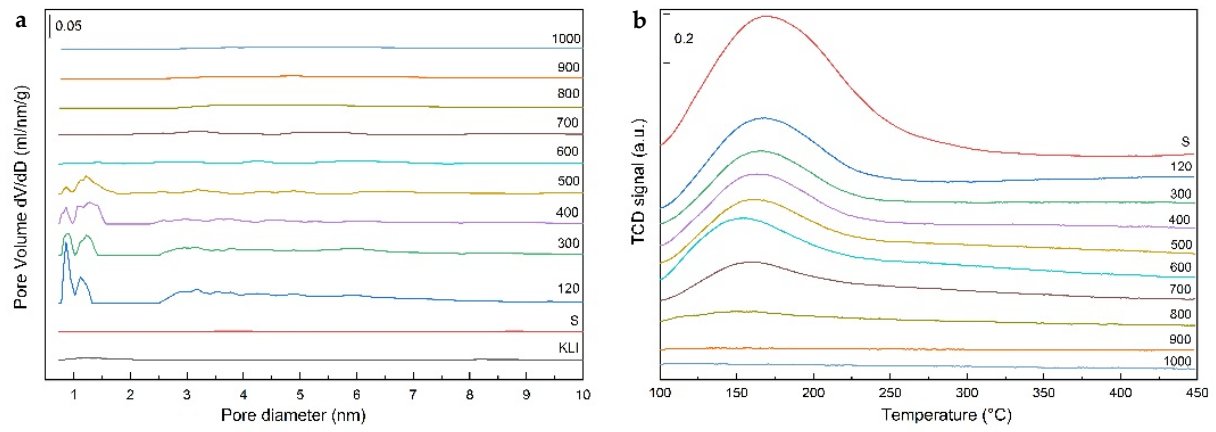

Figure 9. Pore size distribution (a) and $\mathrm{NH}_{3}$-TPD (b) of calcined zeolite foams.

The pictures from the scanning electron microscope (Figure 10) showed the structure of studied samples. Sample "S" (Figure 10a) showed silicate crystals from excess activator which were removed by subsequent two-step leaching. The surface was cleared and a large number of pores were formed (Figure 10b,d). The appearance of the sample calcined at $600^{\circ} \mathrm{C}$ (Figure 10c) was very similar to the 
$120{ }^{\circ} \mathrm{C}$ dried sample and showed no major structural changes. There was only the colour change (Figure 7) associated with the oxidation of Fe present in the structure.

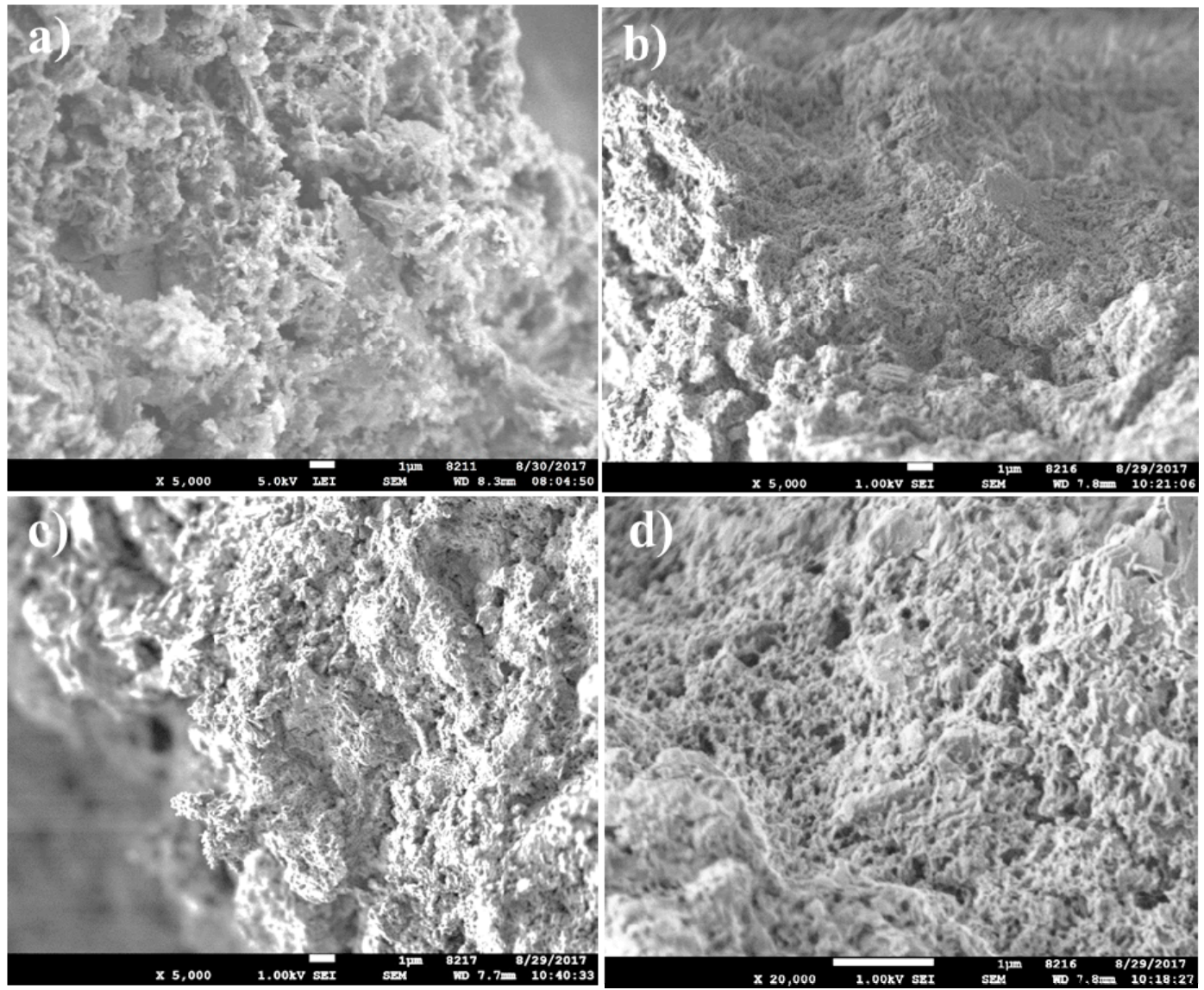

Figure 10. SEM pictures of prepared and modified foams: $S(\mathbf{a}), 0.1 \mathrm{M}+3 \mathrm{M}(\mathbf{b}), 600$ (c)-magnification $5000 \times$, and $0.1 \mathrm{M}+3 \mathrm{M}(\mathrm{d})$-magnification 20,000×.

The amount of acid sites of the calcined samples was determined by $\mathrm{NH}_{3}$-TPD. The TPD curves (Figure 9b) of the calcined samples contained a dominant low-temperature peak whose intensity decreased with increasing of calcination temperature and the peak was not visible at the calcination temperature above $800^{\circ} \mathrm{C}$. The decrease of the intensity was caused by a decrease in the specific surface which also decreased with increasing temperature and by structural changes (dehydration) of the $\mathrm{N}$ (K)-A-S-H matrix and the zeolite phase. A high-temperature peak with a maximum of typically about $300{ }^{\circ} \mathrm{C}$ was not very distinct and the population reached a maximum of $20 \%$ in our samples. Results of the quantitative analysis of the $\mathrm{NH}_{3}$-TPD curves were summarized in Table 7.

The significant decrease in the total number of acid centres was observed in calcined samples compared to the two-step leached dried sample (Table 7). In the region of $300-600{ }^{\circ} \mathrm{C}$, the total acidity was constant and there were not too many changes in the acid sites, due to the retained zeolite structure and the N (K)-A-S-H matrix. This trend was also observed in XRD and DRIFT methods. At higher temperatures, the decomposition of these structures occurred, and the acidity decreased significantly. The initial rapid decrease was because of the dehydration of the sample, where water was removed from the zeolite structure and the binder matrix. For the dried sample, ammonia was primarily bound by a quite strong hydrogen bond to water molecules. At higher temperatures, dehydroxylation of the surface (silanol and aluminol groups) occurs [31].

This study examines the patterns associated with the preparation and possible subsequent use of a group of materials that have been so far the domain of the construction industry. There are some 
studies concerning the alkaline activation of natural zeolites, but not in terms of materials or the study of their properties for use in catalytic and sorption applications. These materials have great potential as it has been proven in a number of national patents and also in our earlier publications [32-34]. Currently, research is going on and the materials or catalysts prepared from them are tested for catalytic decomposition of $\mathrm{N}_{2} \mathrm{O}$ (Co catalysts), deoxygenation of oils, and condensates from aldolization reactions (MoCx/MoNx catalysts), but also for heavy metal sorption applications.

Table 7. Properties of acid sites determined by $\mathrm{NH}_{3}$-TPD.

\begin{tabular}{|c|c|c|c|c|c|c|c|}
\hline Sample & $\begin{array}{c}\mathrm{CSUM}^{\mathrm{C}} \\
(\mathrm{mmol} / \mathrm{g})\end{array}$ & $T_{\max 1}\left({ }^{\circ} \mathrm{C}\right)$ & $\begin{array}{c}\mathrm{c}_{\mathrm{LT}} \\
(\mathrm{mmol} / \mathrm{g})\end{array}$ & $\begin{array}{c}\text { Population } \\
\text { LT (\%) }\end{array}$ & $T_{\max 2}\left({ }^{\circ} \mathrm{C}\right)$ & $\begin{array}{c}\mathrm{c}_{\mathrm{HT}} \\
(\mathrm{mmol} / \mathrm{g})\end{array}$ & $\begin{array}{c}\text { Population } \\
\text { HT (\%) }\end{array}$ \\
\hline 120 & 0.518 & 166 & 0.464 & 90 & 309 & 0.054 & 10 \\
\hline 300 & 0.130 & 164 & 0.109 & 84 & 299 & 0.021 & 16 \\
\hline 400 & 0.136 & 162 & 0.104 & 77 & 299 & 0.032 & 23 \\
\hline 500 & 0.130 & 160 & 0.101 & 78 & 297 & 0.029 & 22 \\
\hline 600 & 0.129 & 152 & 0.108 & 84 & 293 & 0.021 & 16 \\
\hline 700 & 0.081 & 156 & 0.054 & 76 & 262 & 0.028 & 24 \\
\hline 800 & 0.023 & 149 & 0.021 & 92 & 310 & 0.002 & 8 \\
\hline 900 & 0.006 & $-*$ & 0.006 & 100 & - & - & - \\
\hline 1000 & 0.006 & $-*$ & 0.006 & 100 & - & - & - \\
\hline
\end{tabular}

* flat peak without a significant maximum.

\section{Conclusions}

The zeolite foams prepared by alkaline activation of the natural zeolite represent the heat resistant materials in which further post-synthesis treatments can be performed to improve their properties.

Chemical, textural, and acid-base properties can be adjusted by acid leaching and heat treatment. The leaching with mineral and organic acids allows the removal of elements from the structure and the release and purification of the micro- and mesopores of the base zeolite matrix. The release and purification of pores cause an increase of the porosity of the zeolite foam. The two-step leaching is the most advantageous procedure which removes the accompanying elements ( $\mathrm{Al}, \mathrm{K}, \mathrm{Na}, \mathrm{Ca}, \mathrm{Mg}, \mathrm{Fe}$ ) from the structure and perfectly cleans pores, especially the micropores. The two-step leaching does not lead to a collapse of the zeolite structure as it does the high concentrated acids. In addition, the study showed that very similar characteristics can be obtained by different procedures (acid concentration versus temperature or leaching time). The effect of organic acids such as citric acid and tartaric acid is very similar to the use of low concentrated $\mathrm{HCl}(0.1-0.5 \mathrm{M})$. An exception is oxalic acid (compared to $\mathrm{HCl}$ ), which is able to remove aluminium from the zeolite structure even at relatively low concentrations $(1 \mathrm{M})$. The use of weak organic acids or low-concentration mineral acids leads to an increase in the total amount of acid centres. The increase of acid centres is because of gaining the access to acid Lewis sites on the zeolite surface and the $\mathrm{N}(\mathrm{K})-\mathrm{A}-\mathrm{S}-\mathrm{H}$ binder matrix.

The thermal resistance of the material was monitored at temperatures up to $1000{ }^{\circ} \mathrm{C}$. However, at this temperature it is no longer a zeolitic material, since the zeolite structure disintegrates at temperatures above $500-600^{\circ} \mathrm{C}$. The collapse of the zeolite structure has been clearly demonstrated by XRD, DRIFT, and $\mathrm{N}_{2}$ physisorption techniques. At temperatures above $600{ }^{\circ} \mathrm{C}$, the acidity of the zeolite foams decreases, and the material is converted to an inert macroporous ceramics.

Based on these results-it is clear that these materials have, after using other post-synthesis processes, a much wider potential and are applicable not only in the building industry but also in catalytic and sorption applications.

Author Contributions: Conceptualization, Z.T.; methodology, Z.T.; validation, Z.T.; formal analysis, J.Š.; investigation, J.Š., L.P. and K.H.; writing—original draft preparation, Z.T.; writing—review and editing, K.H., E.S.; visualization, E.S., K.H.; supervision, Z.T.

Funding: The publication is a result of the project Development of the UniCRE Centre (project code LO1606) which has been financially supported by the Ministry of Education, Youth and Sports of the Czech Republic 
(MEYS) under the National Sustainability Programme I. The result was achieved using the infrastructure of the project Efficient Use of Energy Resources Using Catalytic Processes (LM2015039) which has been financially supported by MEYS within the targeted support of large infrastructures. Special thanks to the University of Pardubice (Czech Republic) for SEM images processing.

Conflicts of Interest: The authors declare no conflict of interest. The funders had no role in the design of the study; in the collection, analyses, or interpretation of data; in the writing of the manuscript, or in the decision to publish the results.

\section{References}

1. Melenová, L.; Ciahotný, K.; Jirglová, H.; Kusá, H.; Růžek, P. Odstraňování amoniaku z odpadních plynů adsorpcí na zeolitech a jejich následné využití v zemědělství. Chem. Listy 2003, 97, 562-568.

2. Zeocem®, Bystré, Slovenská Republika. 2019. Available online: http://www.zeocem.com/sk/zeolit (accessed on 25 April 2019).

3. Tišler, Z.; Horáček, J.; Šafář, J.; Velvarská, R.; Pelíšková, L.; Kocík, J.; Gherib, Y.; Marklová, K.; Bulánek, R.; Kubička, D. Clinoptilolite foams prepared by alkali activation of natural zeolite and their post synthesis modifications. Microporous Mesoporous Mater. 2019, 282, 169-178. [CrossRef]

4. Iza-structure, Structure Commission of the International Zeolite Association. 2017. Available online: http://www.iza-structure.org/databases (accessed on 29 April 2019).

5. Mansouri, N.; Rikhtegar, N.; Panah, H.A.; Atabi, F.; Shahraki, B.K. Porosity, characterisation and structural properties of natural zeolite-Clinoptilolite-As a sorbent. Environ. Prot. Eng. 2013, 39, 139. [CrossRef]

6. Baerlocher, C.; McCusker, L.B.; Olson, D.H. Atlas of Zeolite Framework Types, 6th ed.; Elsevier: Amsterdam, The Netherlands, 2007; ISBN 978-0-444-53064-6.

7. Kowalczyk, P.; Sprynskyy, M.; Terzyk, A.P.; Lebedynets, M.; Namieśnik, J.; Buszewski, B. Porous structure of natural and modified clinoptilolites. J. Colloid Interface Sci. 2006, 297, 77-85. [CrossRef] [PubMed]

8. Sprynsky, M.; Golembiewski, R.; Trykowski, G.; Buszewski, B. Heterogeneity and hierarchy of clinoptilolite porosity. J. Phys. Chem. Solids 2010, 71, 1269-1277. [CrossRef]

9. Cakicioglu-Ozkan, F.; Ulku, S. The effect of $\mathrm{HCl}$ treatment on water vapor adsorption characteristics of clinoptilolite rich natural zeolite. Microporous Mesoporous Mater. 2005, 77, 47-53. [CrossRef]

10. Alzeer, M.I.M.; MacKenzie, K.J.D.; Keyzers, R.A. Facile synthesis of new hierarchical aluminosilicate inorganic polymer solid acids and their catalytic performance in alkylation reactions. Microporous Mesoporous Mater. 2017, 241, 316-325. [CrossRef]

11. Alzeer, M.I.M.; MacKenzie, K.J.D.; Keyzers, R.A. Porous aluminosilicate inorganic polymers (geopolymers): A newclass of environmentally benign heterogeneous solid acid catalysts. Appl. Catal. A Gen. 2016, 524, 173-181. [CrossRef]

12. Brylewska, K.; Rożek, P.; Król, M.; Mozgawa, W. The influence of dealumination/desilication on structural properties of metakaolin-based geopolymers. Ceram. Int. 2018, 44, 12853-12861. [CrossRef]

13. Bernasconi, S. Liquid Phase Nitration of Toluene and 2-Nitrotoluene Using Acetyl Nitrate: Zeolite BEA as Para-Selective Catalyst. Ph.D. Thesis, Swiss Federal Institute of Technology Zurich, Zürich, Switzerland, 2003.

14. Giudici, R. Synthesis, Dealumination and Adsorption Behavior of Mordenite Extrudates. Ph.D. Thesis, Swiss Federal Institute of Technology Zurich, Zürich, Switzerland, 1999.

15. Mavrodinova, V.; Popova, M.; Mihályi, R.M.; Páł-Borbély, G.; Minchev, C. Transalkylation of toluene with cumene over zeolites Y dealuminated in solid-state. Part II. Effect of the introduced Lewis acid sites. Appl. Catal. A Gen. 2003, 248, 197-209. [CrossRef]

16. Ayrault, P.; Datka, J.; Laforge, S.; Martin, D.; Guisnet, M. Characterization of the Internal and External Acidity of H-MCM-22 Zeolites. J. Phys. Chem. B 2004, 108, 13755-13763. [CrossRef]

17. Giudici, R.; Kouwenhoven, H.W.; Prins, R. Comparison of nitric and oxalic acid in the dealumination of mordenite. Appl. Catal. A Gen. 2000, 203, 101-110. [CrossRef]

18. Lynch, J.L.V.; Baykara, H.; Cornejo, M.; Soriano, G.; Ulloa, N.A. Preparation, characterization, and determination of mechanical and thermal stability of natural zeolite-based foamed geopolymers. Constr. Build. Mater. 2018, 172, 448-456. [CrossRef]

19. Chen, L.; Wang, Z.; Wang, Y.; Feng, J. Preparation and Properties of Alkali Activated Metakaolin-Based Geopolymer. Materials 2016, 9, 767. [CrossRef] [PubMed] 
20. Catauro, M.; Papale, F.; Lamanna, G.; Bollino, F. Geopolymer/PEG Hybrid Materials Synthesis and Investigation of the Polymer Influence on Microstructure and Mechanical Behavior. Mater. Res. 2015, 18, 698-705. [CrossRef]

21. Perná, I.; Šupová, M.; Hanzlíček, T. The characterisation of the Ca-K geopolymer/solidifield fluid fly-ash interlayer. Ceram. Silik. 2017, 61, 26-33. [CrossRef]

22. Tinti, A.; Tugnoli, V.; Bonora, S.; Francioso, O. Recent applications of vibrational mid-Infrared (IR) spectroscopy for studying soil components: A review. J. Cent. Eur. Agric. 2015, 16, 1-22. [CrossRef]

23. Toktarev, A.V.; Malysheva, L.V.; Paukshtis, E.A. Effect of Thermal Treatment Conditions on the Acid Properties of Zeolite Beta. Kinet. Catal. 2010, 51, 318-324. [CrossRef]

24. Boronat, M.; Corma, A. What Is Measured When Measuring Acidity in Zeolites with Probe Molecules? ACS Catal. 2019, 9, 1539-1548. [CrossRef]

25. Pechar, F.; Rykl, D. Infrared spectra of natural zeolites of the stilbite group. Chem. Zvesti 1981, 35, 189-202.

26. Snellings, R.; Mertens, G.; Gasharova, B.; Garbev, K.; Elsen, J. The pozzolanic reaction between clinoptilolite and portlandite: A time and spatially resolved IR study. Eur. J. Mineral. 2010, 22, 767-777. [CrossRef]

27. Braconnier, L.; Clemencon, I.; Legens, C.; Moizan, V.; Diehl, F.; Pilliere, H.; Echegut, P.; Meneses, D.S.; Schuurman, Y. An X-ray diffractometer coupled with diffuse reflectance infrared Fourier transform spectroscopy and gas chromatography for in situ and in operando characterization: An innovative analytical laboratory instrument. J. Appl. Cryst. 2013, 46, 262-266. [CrossRef]

28. Hidalgo, C.V.; Itoh, H.; Hattori, T.; Niwa, M.; Murakami, Y. Measurement of the acidity of various zeolites by temperature-programmed desorption of ammonia. J. Catal. 1984, 85, 362-369. [CrossRef]

29. Akyuz, S.; Akyuz, T.; Basaran, S.; Bolcal, C.; Gulec, A. Analysis of ancient potteries using FT-IR, micro-Raman and EDXRF spectrometry. Vib. Spectrosc. 2008, 48, 276-280. [CrossRef]

30. Pechar, F.; Rykl, D. Study of the thermal stability of the natural zeolite heulandite. Chem. Papers 1985, 39, 369-377.

31. Ekimova, M.; Quevedo, W.; Szyc, Ł.; Iannuzzi, M.; Wernet, P.; Odelius, M.; Nibbering, E.T. Aqueous solvation of ammonia and ammonium: Probing hydrogen bond motifs with FT-IR and soft X-ray spectroscopy. J. Am. Chem. Soc. 2017, 139, 12773-12783. [CrossRef]

32. Tišler, Z.; Šafář, J.; Velvarská, R.; Pelíšková, L. Modifikované Alkalicky Aktivované Zeolitové Pěny: Příprava a Charakterizace. Chem. Listy 2019, 113, 111-116.

33. Hidalgo, J.M.; Tišler, Z.; Vráblík, A.; Velvarská, R.; Lederer, J. Acid-modified phonolite and foamed zeolite as supports for NiW catalysts for deoxygenation of waste rendering fat. Reaction Kinetics. Mech. Catal. 2019, 129, 773-793. [CrossRef]

34. Tišler, Z.; Velvarská, R.; Skuhrovcová, L.; Pelíšková, L.; Akhmetzyanova, U. Key Role of Precursor Nature in Phase Composition of Supported Molybdenum Carbides and Nitrides. Materials 2019, 12, 415. [CrossRef] 